\title{
Regenerative Stem Cell Therapy for Neurodegenerative Diseases: An Overview
}

\author{
Farzane Sivandzade ${ }^{1,2}$ (D) and Luca Cucullo ${ }^{2, * \text { (D) }}$ \\ 1 Department of Biological Sciences, Oakland University, Rochester, MI 48309, USA; fsivandzade@oakland.edu \\ 2 Department of Foundation Medical Studies, Oakland University William Beaumont School of Medicine, \\ Rochester, MI 48309, USA \\ * Correspondence: lcucullo@oakland.edu; Tel.: +1-248-370-3884; Fax: +1-248-370-4060
}

Citation: Sivandzade, F.; Cucullo, L. Regenerative Stem Cell Therapy for Neurodegenerative Diseases: An Overview. Int. J. Mol. Sci. 2021, 22, 2153. https://doi.org/10.3390/ ijms22042153

Academic Editor:

Giuseppe Lazzarino

Received: 29 January 2021

Accepted: 19 February 2021

Published: 22 February 2021

Publisher's Note: MDPI stays neutral with regard to jurisdictional claims in published maps and institutional affiliations.

Copyright: (c) 2021 by the authors. Licensee MDPI, Basel, Switzerland. This article is an open access article distributed under the terms and conditions of the Creative Commons Attribution (CC BY) license (https:/ / creativecommons.org/licenses/by/ $4.0 /)$.

\begin{abstract}
Neurodegenerative diseases resulting from the progressive loss of structure and/or function of neurons contribute to different paralysis degrees and loss of cognition and sensation. The lack of successful curative therapies for neurodegenerative disorders leads to a considerable burden on society and a high economic impact. Over the past 20 years, regenerative cell therapy, also known as stem cell therapy, has provided an excellent opportunity to investigate potentially powerful innovative strategies for treating neurodegenerative diseases. This is due to stem cells' capability to repair injured neuronal tissue by replacing the damaged or lost cells with differentiated cells, providing a conducive environment that is in favor of regeneration, or protecting the existing healthy neurons and glial cells from further damage. Thus, in this review, the various types of stem cells, the current knowledge of stem-cell-based therapies in neurodegenerative diseases, and the recent advances in this field are summarized. Indeed, a better understanding and further studies of stem cell technologies cause progress into realistic and efficacious treatments of neurodegenerative disorders.
\end{abstract}

Keywords: stem cells; therapy; regenerative; neurodegenerative diseases; Parkinson's disease; Huntington's disease; Alzheimer's disease; amyotrophic lateral sclerosis

\section{Introduction}

Neurodegenerative disorders, such as Parkinson's disease (PD), Alzheimer's disease (AD), Huntington's disease (HD), amyotrophic lateral sclerosis (ALS), and frontotemporal dementia (FTD), are characterized by a progressive loss of structure, function, or number of neurons in the brain or spinal cord. Unfortunately, the currently available treatment options are insufficient in arresting the neurodegenerative processes [1]. The complexity of the mechanisms associated with neuronal loss and the contradicting physiological causes of these diseases significantly hinder our understanding of the pathogenic processes and the consequential development of effective treatments [2]. Moreover, difficulty in targeting the widespread neuronal cell death, coupled with the lack of robust regenerative capacity of the central nervous system (CNS) and the enormous limitations for the vast majority of drugs (98\% of small-molecule drugs and 100\% of large-molecule drugs) regarding crossing the blood-brain barrier (BBB) further adds to the difficulty of treating these diseases [3-7]. The loss of quality of life, the cost of care, and the lack of effective therapies are an enormous burden for over 7 million people in the USA living with these neurodegenerative diseases [8].

Stem cell therapy, also known as regenerative therapy, improves the repair response of dysfunctional and damaged tissue using stem cells or their derivatives. The objectives of stem cell therapies typically focus either on cellular replacement or on providing environmental enrichment. Stem cell therapy has revolutionized medicine over the years since its therapeutic applications have provided invaluable and attractive options for treating numerous disorders, including neurodegenerative diseases [9]. The potential of stem cell therapy in neurodegenerative diseases was first examined in the 1980s when 
patients suffering from PD were treated with fetal mesencephalic tissue transplantation [10]. Nowadays, stem cell therapy offers promising strategies for treating almost all forms of neurodegenerative disorders. These strategies involve the regeneration of neural tissue, stabilizing the neuronal networks, providing neurotrophic support, and alleviating neurodegeneration at different neuronal circuitry levels [9]. Scientists are continually trying to find sturdy, safe, and readily available stem cell sources while refining and/or developing new delivery methods to improve the treatment's efficiency and effectiveness and reduce the side effects [11].

This review provides encompassing information on the various types of stem cells and then discusses the existing data, progress, and status of using stem cells to treat neurodegenerative diseases. We also describe the remaining challenges associated with transitioning stem cell therapies from bench to bedside.

\section{Stem Cell Classifications}

Stem cells are characterized by the capacity to proliferate, self-renew, and differentiate into various mature cell lineages. There are different classifications of stem cells, including embryonic stem cells (ESCs), induced pluripotent stem cells (iPSCs), mesenchymal stem cells (MSCs), and neural stem cells (NSCs). The classification is based on the range of possible cell type production and derivation methods. Therefore, it is essential to understand the characteristics of the various available stem cell types and the potential effect of cellular therapies on disease mechanisms (see Figure 1). The rationale for utilizing each type of stem cell depends on the desired applications and outcomes since each type possesses individual qualities and advantages. In the following paragraphs, we summarized the various types and general aspects of stem cells used in basic research and clinical trials (see Table 1).
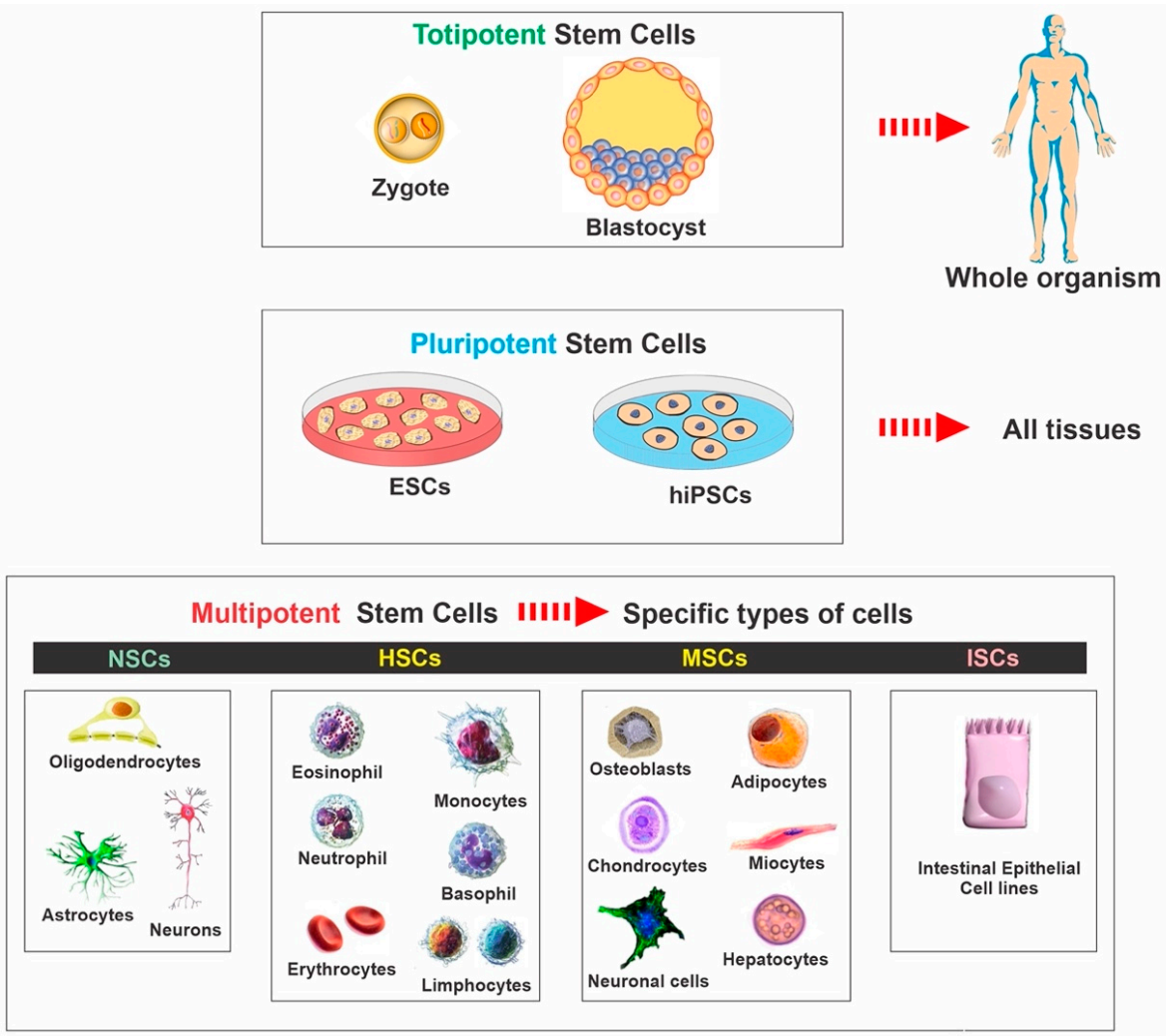

Figure 1. Classification of stem cells: ESCs-embryonic stem cells, hiPSCs-human induced pluripotent stem cells, NSCs-neural stem cells, HSCs-hematopoietic stem cells, MSCs-mesenchymal stem cells, ISCs-intestinal stem cells. 
Table 1. Comparison between the various types of stem cells. This side-by-side comparison includes their origin and the inherent clinical advantages and disadvantages of using these cells.

\begin{tabular}{|c|c|c|c|}
\hline Stem Cell Type & Origin & Advantages & Disadvantages \\
\hline $\begin{array}{c}\text { ESCs } \\
\text { (pluripotent) }\end{array}$ & Embryo (blastocyst) & Unlimited proliferation & $\begin{array}{ll}\checkmark & \text { Ethical problems } \\
\checkmark & \text { Risk of immune rejection } \\
\checkmark & \text { Unpredictable differentiation } \\
\checkmark & \text { High risk of tumor formation }\end{array}$ \\
\hline $\begin{array}{c}\text { IPSCs } \\
\text { (pluripotent) }\end{array}$ & $\begin{array}{l}\text { Reprogrammed adult } \\
\text { cells: fibroblasts, } \\
\text { hepatocytes, circulating } \\
\text { T cells, and keratinocytes }\end{array}$ & $\begin{array}{ll}\checkmark & \text { No ethical problems } \\
\checkmark & \text { Low risk of immune rejection } \\
\checkmark & \text { High accessibility }\end{array}$ & 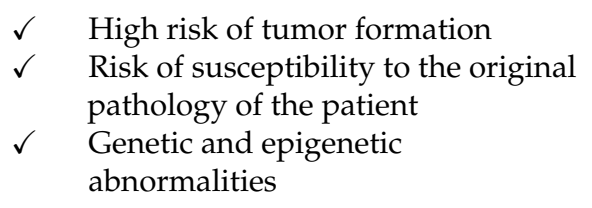 \\
\hline $\begin{array}{c}\text { MSCs } \\
\text { (multipotent) }\end{array}$ & $\begin{array}{l}\text { Adult tissues (bone } \\
\text { marrow, skin, blood, } \\
\text { umbilical cord, etc.) }\end{array}$ & $\begin{array}{ll}\checkmark & \text { No ethical problems } \\
\checkmark & \text { High accessibility } \\
\checkmark & \text { Easy isolation methods } \\
\checkmark & \text { Autologous cells generation } \\
\checkmark & \text { Self-renewal capacity } \\
\checkmark & \text { Low risk of immune rejection }\end{array}$ & Risk of tumor formation \\
\hline $\begin{array}{c}\text { NSCs } \\
\text { (Multipotent) }\end{array}$ & $\begin{array}{l}\text { Embryo, human fetal } \\
\text { brain and brain tissue of } \\
\text { adults (SVZ and SGZ } \\
\text { of hippocampus) }\end{array}$ & Low risk of tumor formation & $\begin{array}{ll}\checkmark & \text { Ethical problems } \\
\checkmark & \text { Risk of immune rejection } \\
\checkmark & \text { Limited differentiation } \\
\checkmark & \text { Low self-renewal capacity } \\
\checkmark & \text { Limited proliferation and expansion } \\
\checkmark & \text { Limited availability } \\
\checkmark & \text { Difficult isolating methods }\end{array}$ \\
\hline
\end{tabular}

SGZ: subgranular zone, SVZ: subventricular zone.

\subsection{Embryonic Stem Cells}

ESCs are a class of pluripotent stem cells derived from the inner cell mass of blastocysts (an embryo that has been left to develop for 5 to 6 days and presents a relatively complex cellular structure formed of approximately 100-200 cells; see Figure 2). ESCs offer promising avenues for research due to their ability to self-renew indefinitely and differentiate into almost all cell types of the central nervous system. These cells are currently being used as an invaluable cell source of human neuronal progenitors in large quantities and high purity in various research areas related to neurodegenerative diseases [12].

Researchers are currently focusing heavily on the therapeutic potential of ESCs. Although ESCs offer new means of treatment, it still raises some thorny ethical and religious restrictions since it involves destroying human embryos [4,13]. Additionally, there are several medical concerns associated with all novel ESC therapies in translational medicine, such as the significant risk of immunorejection in the host patient, as well as tumor formation and cancer as a result of the persistence of nondifferentiated cells undergoing malignant transformation and genetic instability following a prolonged time in culture [14]. 


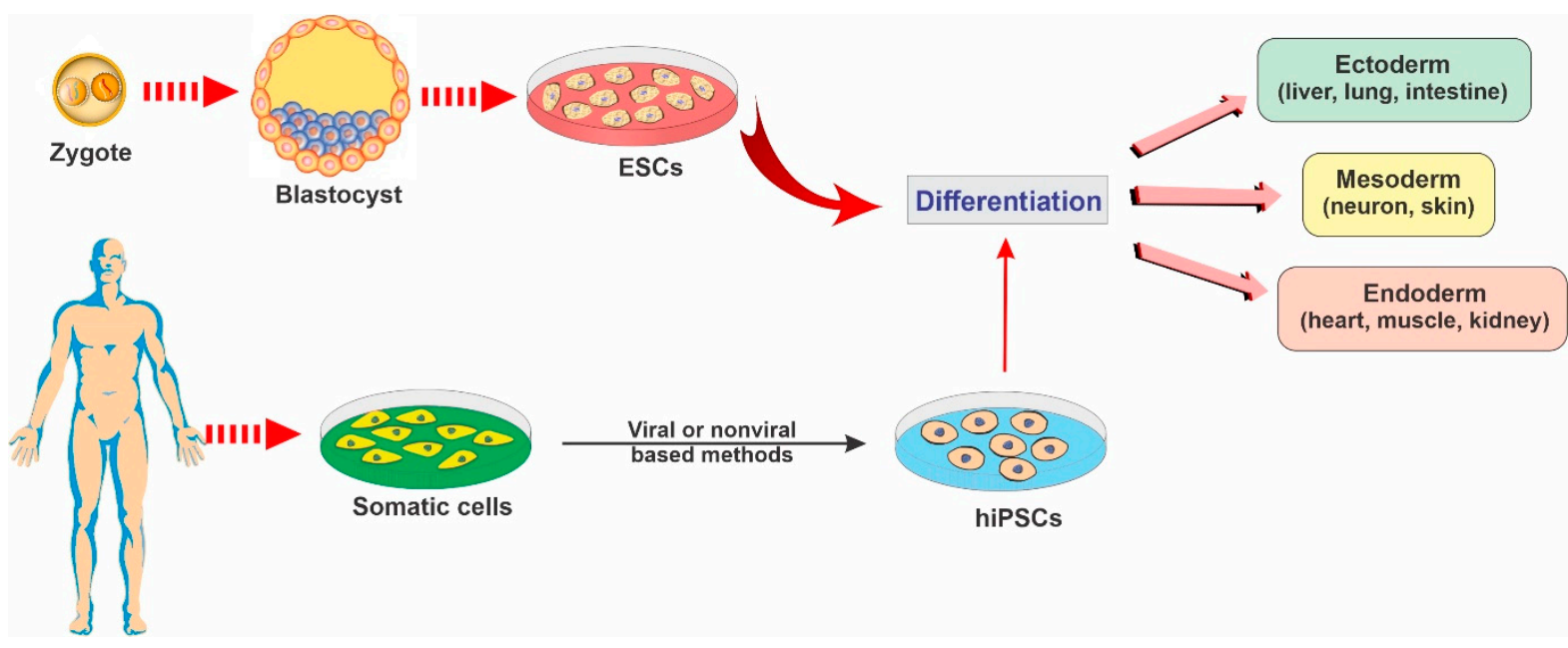

Figure 2. Representative diagram depicting the main types of stem cells and their potential to differentiate into various lineages.

\subsection{Induced Pluripotent Stem Cells}

iPSCs are a type of pluripotent stem cells that are artificially derived from nonpluripotent, adult somatic cells, including fibroblasts, hepatocytes, circulating $\mathrm{T}$ cells, and keratinocytes, by forcing the expression of genes and transcription factors that maintain embryonic stem cells [15]. These reprogrammed cells now provide a promising strategy for producing unlimited autologous neurons for transplantation in neurodegenerative patients [2]. iPSCs can be converted into mature functional neural lineages using an optimized differentiation method, which widens the scope of its potential applications in the studies of the mechanisms underlying various neurodegenerative disorders and the screening of novel therapeutic targets $[16,17]$. For example, in a patient with a neurodegenerative disease, a pluripotent cell can be taken from the skin or blood (see Figure 2). The resulting iPSCs can become a reliable source for generating those neural cells affected by degenerative brain disease [18].

One of the main distinct advantages of iPSCs is the lack of ethical and religious implications because cells can be produced without oocytes or embryos. Another significant merit of iPSCs is that they can be generated from the patients themselves, thus providing a valuable avenue for autologous cell transplantation with no risk of immune rejection and no need for immunosuppressive agents $[19,20]$. iPSCs offer potential clinical advantages due to more straightforward harvesting methods and fewer possible side effects, with better specific terminally differentiated cell phenotypes. However, the differentiation of IPSCs into mature neurons is more complicated than for ESCs. Like ESCs, there is still the risk of tumor formation due to unwanted viral integration, causing chromosomal disruptions and mutations and low reprogramming efficiency during these cells' production [14,21]. Hence, the clinical application of IPSCs in neurodegenerative diseases is still not feasible yet, owing to the lack of in-depth research evaluating its therapeutic safety among human subjects.

\subsection{Mesenchymal Stem Cells}

MSCs, which are traditionally found in the bone marrow, umbilical cord, adipose tissue, and spleen, are adult, self-renewing, multipotent stem cells that can differentiate into various cell types, including bone, cartilage, fat, and muscle [22]. MSCs have enormous therapeutic potential and could be an ideal source for cell transplantation in neurodegenerative diseases due to their excellent self-renewal capacity while maintaining multipotency [23]. MSC-derived functional neurons appear to be more promising regarding neurodegenerative diseases than ESCs due to the relatively easy collecting methods and fewer related ethical, religious, and immunorejection concerns [24]. Furthermore, 
MSCs do not organize tumors like other primitive stem cells, such as ESCs [25]. Thus, the promising abilities of MSCs present them as an attractive platform for research into neurodegenerative disorders. Several studies have also indicated that MSCs might possess the ability to cross the BBB, which is crucial for the proper delivery of neurotherapeutic agents into the CNS [26,27]. It has been shown that MSCs can cross the BBB through paracellular pathways, despite the presence of tight junctions that would normally block such passages [28]. There are preclinical studies and ongoing clinical trials currently assessing the therapeutic effectiveness of MSCs in various neurodegenerative diseases. MSCs are delivered via either intracerebral or intrathecal injections. Following transplantation, MSCs initiate their neuroregenerative function, including promoting neuronal growth, producing neurotrophic factors, stimulating endogenous neurogenesis, activating microglia, suppressing inflammation, and decreasing apoptosis and free radicals [18]. MSCs can also secrete angiopoietin-1, angiogenic cytokines, and extracellular matrix components, thus improving angiogenesis and promoting the recruitment of neural progenitor cells (NPCs) [29].

\subsection{Neural Stem Cells}

NSCs are multipotent stem cells in brain tissue that are more specialized than ESCs. NSCs have a decreased potential for self-renewal and usually differentiate into only limited cell lineage of the brain tissue, including oligodendrocytes, neurons, and astrocytes [13,30] (see Figure 2). NSCs can be derived from various regions of both the embryonic and the human fetal brain or the brain tissue of patients undergoing surgical therapies [30-33].

The transplantation of NSCs to other brain regions is considered a possible therapeutic avenue for the treatment of many neurodegenerative diseases [1,34]. For example, NSCs can play a role in gliogenesis by releasing bioactive molecules that regulate neuronal excitability, synaptic activity, and plasticity [35]. NSCs can also generate and release synergistic and antagonistic molecules, triggering intracellular NSC regulatory mechanisms, such as transcription factors, epigenetic responses, and metabolism [36]. Furthermore, NSCs can establish synaptic connections with surrounding neurons, integrate into existing circuitry, and repair the impaired network [37]. Of note, unlike ESCs, NSCs are considered genetically stable and less tumorigenic. The low self-renewal potential of NSCs can be resolved via the genetic modification of these cells to produce immortalized NSCs with enhanced proliferative potential [38]. However, there are still significant obstacles for the therapeutic application of NSCs due to the inevitable possibility of immunological incompatibility in allogeneic transplantation, limited sources, difficulties in isolating these cells, limited proliferation and expansion, and ethical and religious issues [39].

\section{Neurodegenerative Diseases and Stem Cell Therapy Strategies for Regeneration}

Neurodegenerative diseases, including PD, AD, HD, ALS, and FTD, are disorders of protein homeostasis characterized by the loss of specific neuronal populations and inclusion bodies consisting of insoluble and unfolded proteins. This pathogenic process leads to the progressive loss of sensation, cognition, motor neurons, and gradual paralysis. Despite billions of dollars in clinical trials and tremendous progress in understanding the mechanism of neurodegenerative disorders, there are still no detectable biomarkers or effective drugs to slow these diseases' progress.

Although stem cell therapy is still in its infancy, it has become a safe, engaging, and beneficial strategy to be tested in treating neurodegenerative diseases [40]. The first objective of stem cell therapy for neurodegenerative disorders includes deriving specific neuronal subtypes and recapitulating a neural network similar to the one lost in the disease. Another approach for treating neurodegenerative disorders is creating environmental enrichment to support host neurons by producing neurotrophic and scavenging toxic factors or building auxiliary neural networks around affected areas [8]. Many strategies utilize stem cells to provide de novo synthesis and the delivery of neuroprotective growth factors (such as glial-derived neurotrophic factor (GDNF), brain-derived neurotrophic 
factor (BDNF), insulin-like growth factor 1 (IGF-1), and vascular endothelial growth factor (VEGF)) at the site of disease for environmental enrichment.

In recent years, investigators have carried out extensive efforts to produce neurons and glial cells from various stem cells and exploit other beneficial stem cells' aspects to treat neurodegenerative diseases. Multiple sources of stem cells have been examined to determine the most efficacious and productive method for the stem cell therapy of neurodegenerative diseases [41-43]. Most of the research on stem-cell-based therapy for neurodegenerative diseases has been conducted preclinically in animal models. These studies have shown that stem cells could impact endogenous cells, promote the functional recovery of nervous tissue, differentiate into neuronal and glial cells, and decrease motor impairments [44,45]. Many clinical studies are investigating different aspects of stem cell therapies for neurodegenerative disorders [44,46,47]. So far, the data seem to support the results obtained from preclinical studies to some extent. For example, there is a consensus of data showing that neuroprotection is achieved by the secretion of growth factors (such as brain-derived neurotrophic factor, glial cell line-derived neurotrophic factor, and nerve growth factor), which is the fundamental mechanism for the observed improvements in neurodegenerative disorders [48]. Additionally, there is significant evidence showing that stem cell therapies can enhance neurogenesis in neurodegenerative patients [49-51] (see Figure 3).

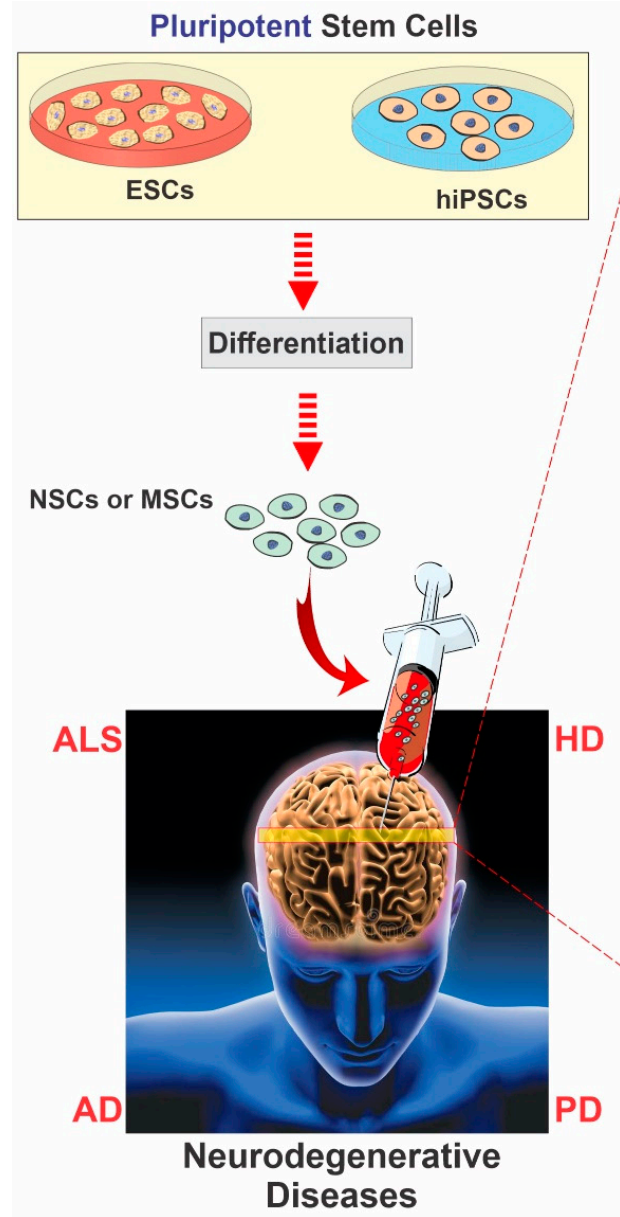

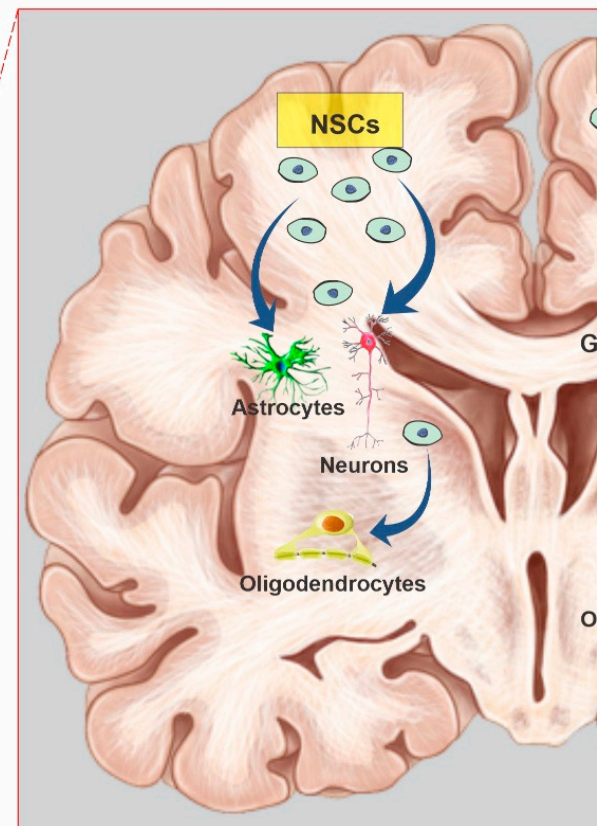

Transdifferentiation

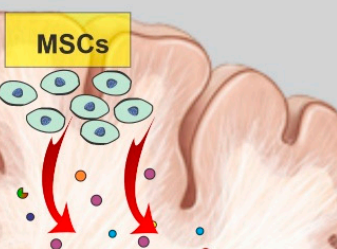

VEGF 'BDंNF

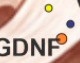

ObFF IGF-1 IGF- $1_{0 \circ}^{\circ}$ - Neurons - $\circ$ - - ${ }_{3}$ Oligodendrocytes Astrocytes igodendrocytes

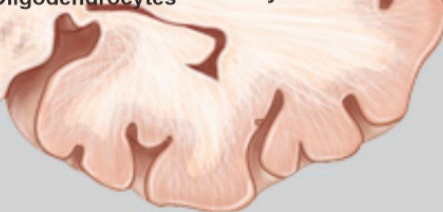

Secretion of neuroprotective factors

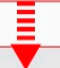

- Enhanced neuronal regeneration

- Restoration of damaged neuronal network

Figure 3. Neurodegenerative disease modeling of hiPSCs and ESCs. These cells can be differentiated into neuronal progenitor (NPCs) and MSCs, from which brain cells, such as oligodendrocytes, astrocytes, and different neuronal and glial lineages, can be generated. Note also that the trophic action of MSCs, including the secretion of growth and neurotrophic factors, can act as a coadjuvant to nervous tissue regeneration by promoting angiogenesis, neurogenesis, and immunomodulation. AD: Alzheimer's disease, ALS: amyotrophic lateral sclerosis, HD: Huntington's disease, PD: Parkinson's disease; BDNF: brain-derived neurotrophic factor, bFGF: basic fibroblast growth factor, IGF-1: insulin-like growth factor 1, GDNF: glial-derived neurotrophic factor, VEGF: vascular endothelial growth factor. 
Moreover, selecting the appropriate stem cell type and understanding the mechanism of support and the specific neuronal pathology are the main steps in developing and translating stem cell therapies from the bench to patients. For example, cellular replacement may be useful in PD, where a specific neuronal subpopulation is lost. In contrast, ALS is most likely to benefit from cellular therapies that enrich the local spinal cord environment to support the remaining motor neurons [8]. Hence, in the following paragraph, we discussed the mechanism of neurogenesis and the pathophysiology of common neurodegenerative diseases. Next, we describe the currently supported approaches and successful progress in translating stem cells from the bench to the bedside regarding curing those specific neurodegenerative diseases.

\subsection{Stem Cell Therapy in Parkinson's Disease}

Dopamine (DA), a key neurotransmitter that transmits signals between neurons, plays an essential role in motor control. PD is the second-most-common age-related progressive neurodegenerative disorder caused by DA deficits in the striatum due to the destruction of DA-producing neurons located in the substantia nigra [52-54]. The initial symptoms are sometimes barely noticeable, such as tremors affecting one hand or the slowing of movement. As the disease progresses, controls over movement are entirely compromised, and patients may present symptoms such as muscle tremors, muscle rigidity, slowing of voluntary movement, postural instability, bradykinesia, and other motor dysfunctions, usually in the fifth to seventh decade of life [24]. To date, approximately 60,000 Americans are diagnosed with PD yearly, and more than ten million people worldwide are suffering from PD [55].

A specific diagnosis of PD includes the presence of Lewy bodies in the brains, which are abnormal protein aggregates developing inside nerve cells and found in both familial and sporadic PD patients. The main constituent of Lewy bodies is $\alpha$-synuclein protein, a small protein with 140 amino acids that are abundantly found in presynaptic nerve terminals and play a role in synaptic transmission and DA level adjustments. $\alpha$-Synuclein primarily affects tyrosine hydroxylase phosphorylation, activity, and DA transporter expression on the cell membrane [56].

The current treatment options for PD include deep brain stimulation or therapies to increase DA levels by providing a DA precursor (Levodopa) to compensate for the deficit in DA caused by the destroyed dopaminergic neurons [57]. Although current medications have proven helpful in alleviating the symptoms, they cannot reverse the significant loss of dopaminergic neurons over time as the disease progresses. On the other hand, several different factors, including protein folding and dysfunction of the ubiquitin-proteasome pathway, mitochondrial dysfunction, and oxidative stress, have been discovered to contribute to the onset and progression of the disease [2,58]. Thus, the heterogeneity in pathology and underlying causes of PD makes its treatment challenging.

Over the past two decades, researchers have been looking for alternative strategies to supplement DA by replacing the dopaminergic neurons lost in the disease with stemcell-derived equivalents. ESCs, NSCs, and iPSCs are among the stem cell typologies that scientists are working with to induce their differentiation into the mature dopaminergic cell [59]. Stem cell therapy for the treatment of PD has demonstrated some success in animal models. Clinical trials have just started employing the transplantation of brain cells isolated from human fetuses into PD-diagnosed patients to assess the procedure's efficacy while minimizing the possible side effects. For example, Schwarz et al. used humanfetus-derived dopaminergic neurons and transplanted them into PD patients' depleted striata [60].

Furthermore, Takagi et al. demonstrated functional recovery after successfully transplanting dopaminergic neurons from monkey ESCs into PD patients' brains [61]. Another study also confirmed the influential role of undifferentiated ESCs in functional recovery by differentiating dopaminergic neurons in a PD rat model [55]. Two other clinical studies using human ESCs are ongoing in Australia and China, where their preclinical studies' 
results were reported [62,63]. Specifically, Garitaonandia et al. [62] described the preclinical tumorigenicity and biodistribution safety in vitro before conducting a phase I clinical trial to evaluate the safety and tolerability of parthenogenetic stem cells for the treatment of PD [62]. In the other study, Wang et al. [63] investigated the ability of human ESCs regarding neuronal differentiation and their potential to produce DA neurons. Using nonhuman primate models of Parkinson's disease, the investigators tested these DA neurons ${ }^{\prime}$ safety and efficacy to assess the optimal processes for employing stem cell therapy in PD patients [63].

Moreover, ESCs have shown excellent outcomes in mice models due to their ability to form dopaminergic neurons for treating PD, which has not been accomplished while using adult neural stem cells. Moreover, in rat models with spinal cord injuries, ESCs showed migration into the parenchyma and spinal cord. They led to partial motor recovery, giving rise to the ultimate goal of reversing motor degeneration in PD. While these studies initially revealed promising results, they were banned due to ethical and religious concerns and the risk of tumorigenesis [64]. Besides ESCs, NSCs have also shown promising results. Because NSCs have a dopaminergic interneuron phenotype, they can release DA, thus alleviating PD symptoms. Deleidi et al. reported the successful differentiation of adult NSCs into functional midbrain dopaminergic neurons in the subventricular zone (SVZ) to improve motor deficits in a PD rat model [65]. Yasuhara et al. transplanted human NSCs into a rat model of PD, thus alleviating the disease's symptoms [66]. In another model, nuclear-1-receptor-engineered NSCs derived from the SVZ and differentiated into dopaminergic neurons in the rat model of PD resulted in reversed behavioral deficits in those animals.

MSCs have also been shown to reduce dopamine depletion and rebuild the damaged striatal dopaminergic nerve terminal network in a PD animal model [18]. A more recent in vivo study revealed that stem cell therapy with human amniotic fluid stem cells and MSCs ameliorated bladder dysfunction [67]. In a pilot clinical trial on seven patients who received MSC transplantations in the lateral ventricles' walls, Venkataraman et al. reported promising functional recovery with no adverse effects and improved dyskinesias [68]. Moreover, in a recent study on 53 patients diagnosed with PD, engineered MSCs differentiated into dopaminergic cells were directly implanted into an artery that feeds the substantia nigra [55]. The results revealed that intra-arterial autologous stem cell implantation is a safe and beneficial procedure that eliminates the risks of tumor formation and immunological attacks.

iPSCs have proven to be very useful for promoting dopamine replacement in patients with PD. Several studies have shown that dopaminergic neurons derived from iPSCs grafted into PD model systems can survive and integrate into the host network with remarkable functional improvements [69]. Other studies also demonstrated that the transplantation of reprogrammed iPSCs into dopaminergic neurons improved functional deficits and cell integration in vivo [70]. These data suggest that iPSCs provide a suitable approach for autologous cell-based therapy in PD [71]. Through a preclinical study, Doi et al. confirmed the safety and efficacy of iPSC-derived DA progenitors for providing long-time survival and functionality of the grafted cells as DA neurons for clinical trials on PD patients [72]. iPSCs offer many advantages, including minimal immune response from the host post-transplantation and a noninvasive method of iPSC isolation from peripheral blood cells $[73,74]$. However, a drawback of iPSCs is that these cells need to be induced to become dopamine-producing neurons, where the process can be quite laborious and expensive [75].

Although cellular replacement is considered a viable approach for treating PD, environmental enrichment through growth factor delivery may also support existing DA neurons' ability to slow or prevent further degeneration. More recent work has focused on encapsulating the desired cell line into a semipermeable polymer, along with a pool of neurotransmitters and neurotrophic factors. This approach combines cellular replacement and environmental enrichment strategies. For example, the transplantation of NSCs derived 
from the SVZ and the nerve growth factor (NGF) in the striatum of animal PD models showed remarkable recovery [46]. Taken together, the combination of cellular replacement and environmental enrichment may improve the efficacy of stem cell therapies for PD treatment. Overall, PD has emerged as a well-suited neurodegenerative disease for stem cell therapy, although careful considerations need to be made when evaluating the potential risks of graft-induced dyskinesias [40,75]. Politis et al. indicated an increased serotonin-toDA-transporter ratio in the grafted striatum after 14 years of transplantation [76].

\subsection{Stem Cell Therapy in Alzheimer's Disease}

$\mathrm{AD}$ is the most common progressive neurodegenerative disorder characterized by the degeneration of synapses and loss of neurons in the hippocampus and the neocortex [52]. AD progression leads to memory decline, judgment impairment, disorientation, loss of language and problem-solving skills, and in the advanced stage, dementia and eventually death $[77,78]$. AD occurs in two forms: (1) early-onset familial (due to genetic mutations), affecting patients less than 65 years old, and (2) late-onset sporadic forms involving patients over 65 years of age. The late form of AD seems to be associated with genetic polymorphisms, aging, type 2 diabetes, traumatic brain injury, stroke, and Down syndrome [55].

While AD's exact pathology remains unclear, the pathologic hallmarks of $\mathrm{AD}$, which lead to decreased synaptic signaling and eventually neuronal death, involve the formation of extracellular senile plaques (SPs, composed of small A $\beta$ peptides) and intracellular neurofibrillary tangles (NFTs). NFTs deposited inside the cell are made of hyperphosphorylated tau proteins that form tangles after dissociating from destabilized microtubules [24]. A $\beta$ plaques, which are deposited outside of neurons, are formed from the amyloid precursor protein fragments. In addition to massive neuronal death and synaptic dysfunction resulting in a profound shrinkage in brain volume and weight, especially in the telencephalon, imbalanced mitochondrial activity is another pathogenesis of AD [79]. Imbalanced mitochondrial activity leads to decreased mitochondrial adenosine triphosphate concentrations, oxidative stress, and increased intracellular calcium levels [56].

Alzheimer's is the sixth-leading cause of death, with a substantial economic burden on society [80,81]. Approximately 5.3 million Americans suffer from AD, including 5.1 million individuals over the age of 65 [82]. Current therapeutic strategies have focused on the breakdown of $\mathrm{A} \beta$ plaques and NFTs and the reduction of reactive oxygen species (ROS) in the brain [24]. AD's current treatment option focuses on promoting cell survival, substituting the lost neurons, and regulating neurotransmitter activity. However, none of the medications currently approved by the U.S. Food and Drug Administration (FDA) are curative and fully efficient across patients [78].

Evidence supports that stem cell therapies may play a beneficial role in slowing $\mathrm{AD}^{\prime}$ 's progression through enhancing neurogenesis, replacing lost neurons, and providing environmental enrichment. Human NSCs have been proven to be a promising source, improving synaptic plasticity, reducing the pathology's burden, and ameliorating spatial learning and memory dysfunction by increasing the expression of multiple cognitionrelated proteins in vivo in $\mathrm{AD}$ mouse models [83-85]. Of note, no reduction in $\mathrm{A} \beta$ or tau pathology was diagnosed, indicating that the regenerative capacity of NSCs could help to balance the degenerative processes occurring in the $\mathrm{AD}$ brain but does not treat the underlying pathology [86]. NSCs transplanted in the hippocampus improved memory deficits in an AD mouse model by releasing BDNF and improving cognitive function [9]. Furthermore, transplanted NSCs migrate and differentiate into various brain cells (including cholinergic neurons, astrocytes, and oligodendrocytes), stimulate endogenous neural precursors, promote structural neuroplasticity, inhibit pro-inflammatory cytokines, suppress neuronal apoptosis, and release growth factors. Kern et al. also revealed that NSCs transplanted into the hippocampus of aged Down syndrome mice promote a striking decrease in the tau/reelin-positive granule density [87]. Overall, the mechanism of action underlying how NSCs promote neurogenesis and cognitive function is still unclear. 
Furthermore, the generation of non-neuronal glial cell types with NSC transplantation is still a limiting factor in AD treatment with stem cell therapies [88].

The use of patient-specific iPSCs in the treatment of AD is still a work in progress. Scientists have employed a novel way to directly create functional neurons from AD patients' skin cells converted into ESCs $[89,90]$. In a recent study, iPSC-derived cholinergic neuronal precursors transplanted in the hippocampus of transgenic $\mathrm{AD}$ mice were differentiated into mature cholinergic neurons and reversed spatial memory impairment. However, the use of iPSCs for neuroreplacement in AD treatment may carry a non-negligible risk of tumor formation since these cells have a highly proliferative phenotype [88]. Fortunately, adult cells can be programmed into mature neurons without reversing them into their stem cell phenotypic form, thus eliminating the tumor formation risk [91,92].

Several studies reported that MSCs stimulate neurogenesis, synaptogenesis, neuronal differentiation and influence amyloidogenesis and/or microglial activation, thus reducing $A \beta$ accumulation and cognitive recovery [93-97]. For example, Kim et al. and Ma et al. indicated that MSCs could alleviate memory impairments and reduce the amount of $A \beta$ in AD mouse models by upregulating interleukin-10 and vascular endothelial growth levels factor while modulating microglial activation in the brain [98]. Moreover, Kan et al. showed that MSCs transplanted into an AD model induced the proliferation, differentiation, and maturation of endogenous NSCs toward a neuronal phenotype [99]. Martinez-Morales et al. also reported that MSCs could produce neurotrophic factors to stimulate endogenous neurogenesis, angiogenesis, and neuronal defense systems [100]. The clinical trials for AD treatment are still in their infancy, where the FDA approved the first clinical trial of MSCs for AD treatment in 2015. Similar trials are currently underway or under development in Europe and Asia to assess the safety, tolerability, and preliminary efficacy of human MSCs in patients with mild-to-moderate AD [101].

Recently, combining stem cells with NGF was recognized as a useful strategy for preventing cell death, stimulating the growth of cholinergic neurons, and facilitating the generation of specific neural populations in AD treatment. NGF gene therapy has been studied in many animal models and has led to successful clinical trials in AD patients [102].

\subsection{Stem Cell Therapy in Huntington's Disease}

HD is a fatal progressive neurodegenerative disorder of autosomal dominant inheritance characterized by the loss of GABAergic inhibitory spiny neurons in the striatum of the forebrain, accompanied by degeneration in the cortex, brain stem, and hippocampus [52]. The HD's pathophysiology is focused on the abnormal expansion of cytosine-adenineguanine (CAG) encoding repeats at the $\mathrm{N}$-terminal of the huntingtin protein $(\mathrm{Htt})$, leading to the preferential loss of medium spiny neurons of the striatum and giving rise to involuntary motor activity, dementia, and cognitive and emotional deficits [8]. The progress of HD typically occurs in the fourth to fifth decade of life, with a disease course of approximately 20-30 years. Despite the known genetic basis and disease mechanisms of HD, the identification of effective therapies remains elusive.

Stem-cell-based therapeutic approaches have received considerable attention as potential treatments for HD. The objective of stem cell therapy for HD is to replace the damaged or lost neurons and modify the mutant genes containing the expanded CAG repeats. Based on recent studies, NSCs have been the type of stem cells most used for HD treatments. NSCs have been derived and induced from various sources, such as the brain itself and the somatic cells of HD patients. Despite the early stage of stem-cell-based preclinical and clinical trials in HD, there is convincing evidence regarding stem cells' transplantation or their derivatives in HD animal models. Initial stem cell therapies focused on ESC-derived NSCs grafted into HD models have demonstrated the integration of motor neurons and circuitry formation in the host. However, the ethical and religious implications of fetal tissues are still crucial issues [103]. The dangers of stem cell therapies, such as graft overgrowth and non-neuronal cells within grafts, should be considered. 
A study on the brains of murine models of HD by Ebert et al. observed that mousederived NSCs act as GDNF delivery vehicles, playing a beneficial role in reducing neuronal death and the resultant motor impairment [104]. To address the role of environmental enrichment in stem cell therapy for HD, engineered NPCs that overexpress GDNF were transplanted into HD rodents. Although unmodified NSCs showed no neuroprotective effects, NPCs expressing GDNF afforded neuron protection and functional recovery.

At present, MSCs offer a promising source of cells for treating HD because of their ability to decrease immune cell dysfunction, enhance compensatory neurogenesis, reduce apoptosis, activate mitochondrial function, and promote cell survival [103].

In 2010, Dey et al. reported that MSCs genetically engineered to overexpress BDNF or NGF decreased behavioral deficits and neuronal loss in the striatum in the YAC 128 mouse model of HD [105]. Thus, transplantation of MSCs overexpressing BDNF may provide a conducive environment within the striatum to slow neurodegenerative processes [9]. Snyder et al. discovered that implanting human-derived MSCs into the dentate gyrus of the hippocampus of mice models of HD could enhance the proliferation and neural differentiation of endogenous NSCs [106]. Moreover, Lin et al. showed that humanderived MSCs offered neuroprotection and neurorestoration through neural differentiation, neurotrophic support capability, and antiapoptotic effects. The result was a significant reduction in motor dysfunction in a mice HD model [107]. Other studies also demonstrated that dental pulp stem cells might be a potential therapeutic source with less post-transplant immune rejection for HD treatment [108]. Similar functional benefits of NPC striatal injections into HD rodents were also demonstrated [8]. These include NPC incorporation into and migration to secondary sites associated with HD disease, resulting in functional improvements.

There are only two reported studies investigating iPSC-derived NSCs for cell replacement therapy for HD. In the first study, Jeon et al. transplanted hiPSC-derived NSCs generated from an HD patient with 72 CAG repeats into an HD mice model and reported an improved functional outcome and no aggregates of human mutant huntingtin (mHTT) in transplanted cells [109]. In subsequent research, mouse iPSC-derived NSCs were transplanted into the lateral ventricle of normal mouse brains and indicated the aggregation of mHTT after 33 weeks. Thus, it seems that the autologous transplantation of HD patientderived cells carrying the HD mutation causes the HD phenotype and cell death persistence. In the second study, An et al. modified an HD-patient-derived iPSC mutation and subsequently generated human neural stem cells (hNSCs) for transplantation into an HD mice model. The transplanted cells not only survived but successfully differentiated into motor neurons [110].

To date, stem cell therapy is still far away from the clinical setting for the treatment of HD since almost all the studies have been conducted in animal models. More in-depth, comprehensive preclinical studies will be needed to confirm its therapeutic potential.

\subsection{Stem Cell Therapy in Amyotrophic Lateral Sclerosis}

ALS (also known as Lou Gehrig's disease) is a progressive, incurable neurodegenerative disease characterized by motor neurons' deaths in the spinal cord's ventral horn and the motor cortex. With the disease progression, symptoms such as motor weakness, twitching, stiffness, and loss of voluntary movement control become apparent [9,52]. The average progression of ALS from onset to death is 20 to 48 months. For most of the last two decades, the mutation of $\mathrm{Cu}-\mathrm{Zn}$ superoxide dismutase 1 (SOD1) was the only genetic aberration associated with familial ALS onset. Studies have unveiled additional abnormalities that may be related to the onset of sporadic and non-SOD1 familial ALS [56]. These include the impairment of neuronal cytoskeletal function, protein instability, aggregation and degradation of RNA/DNA-binding proteins, and the detrimental roles of non-neuronal cells (such as astrocytes) that can be toxic and degenerative to motor neurons [111]. Several factors cause difficulty in finding effective therapies for ALS. Most of the cases are sporadic, with a combination of genetic mutations and/or presumed environmental variables. Thus, the 
diversity of potential causes of the disease means that any therapy would only be effective on a specific subset of patients. Unfortunately, despite the advent of modern medicinal chemistry, there is only one FDA-approved treatment, Riluzole, which provides modest therapeutic effects [112].

Stem cell therapies have generated widespread interest as a potential therapeutic approach. However, no conclusive results have yet been reported, either from preclinical or clinical studies. The unknown pathogenesis and the lack of proper knowledge of the disease's spreading mechanism in the human body are among the most critical barriers to overcome regarding choosing the ideal cell type and optimal anatomical site for implantation.

Theoretically, the underlying strategies for treating ALS using stem cell therapies are similar to those previously described for other neurodegenerative diseases: (1) replace the damaged/dead motor neurons, (2) regulate inflammation, and (3) promote the expression of neurotrophic factors. The treatment's end goal is equally similar to those previously described: provide both an integrated neural component and the necessary environmental enrichment to prevent existing motor neurons from degenerating [8]. The first FDAapproved clinical trial to use fetal-spinal-cord-derived NPCs in ALS patients was initiated in 2010 at Emory University. The trial's scope was to assess the safety of implanting NSCs into the spinal cord of 18 affected patients [113]. Then, Martinez et al. assessed stem cell transplantation's safety in the frontal motor cortex of 67 patients with ALS [114]. Numerous clinical trials on stem cell therapy for ALS evaluated the safety and feasibility of intraspinal, intrathecal, and intracerebral MSC transplants [115]. For example, surgical implantation of MSCs into the dorsal spinal cord also showed no immediate or long-term complications during a follow-up period of 9 years [116]. Indeed, these trials provided significant insight into the safety and feasibility of autologous MSC-based therapies in ALS patients [117]. Besides safety, the efficacy of the treatment needed to be evaluated. A study on 11 ALS patients in Spain demonstrated increased motor neuron numbers and reductions in the presence of ubiquitin deposits in motor neurons following MSC transplantation [118]. Current clinical trials are also focused on the exogenous transplantation of NSCs due to valid data indicating the slow progression of ALS upon the injection of fetal NSCs into the spinal cord of patients [119]. The crucial neuroprotective effect of growth factors on the remaining motor neurons and the stem cells' ability to provide environmental enrichment through growth factor expression is currently being evaluated. For example, Brainstorm Therapeutics is developing an approach to inject MSCs into the fluid surrounding the brain and spinal cord (via intrathecal administration) of ALS patients. The study's scope is to assess the beneficial effects of the neurotrophic pro-angiogenic, anti-inflammatory, and immunomodulatory factors secreted by MSCs [120].

Altogether, although stem cell therapy in ALS treatment is still in its infancy, researchers worldwide hope treatments like this will stop the disease's progression and improve the efficacy of current drug therapies [121].

\subsection{Stem Cell Therapy in Frontotemporal Dementia}

FTD, an insidious neurodegenerative clinical syndrome, is the second-most-common leading cause of neurodegenerative dementia and is usually found in people younger than 65 [122-124]. FTD is characterized by progressive deficits in personality, cognition, behavior, and language functions caused by the selective death of cerebral cortex neurons and neurodegeneration of the frontotemporal cortex $[125,126]$. FTD clinically overlaps with some motor disorders, including progressive supranuclear palsy (PSP), corticobasal syndrome (CBS), parkinsonian disorders (FTD-PD), and motor neuron disease (FTD-MND or FTD-ALS) [127]. FTD is a genetically and pathologically complex disorder occurring in both familial and sporadic forms [125]. Statistically, familial forms of FTD represent about $20-30 \%$ of FTD and up to $15-20 \%$ of these patients carry mutations in the MAPT gene encoding the microtubule-associated protein tau [128-131]. The growing prevalence of FTD with the lack of treatments and the burden on society make FTD a public health 
priority. Therefore, it is crucial to unravel the pathological mechanisms of FTD to identify intervening biomarkers to establish more useful diagnostic guidelines and discover novel therapeutic targets. The genetic origin of a significant proportion of the familial and sporadic forms of FTD is still unknown. However, genetic mutations in tau (MAPT), progranulin (PGRN), and C9ORF72 are among the most common causes of FTD known up to now [132]. These genes have recently been targeted for studying pathological mechanisms and discovering new pharmacological interventions for FTD. However, despite useful research findings over the past two decades, the FTD mechanisms are still poorly understood. This might be due to the lack of appropriate disease models that accurately recapitulate FTD's complex pathologies. Moreover, there are still challenging and misguided cases in the clinical diagnosis of sporadic FTD that rely on clinical diagnostic criteria. The generation of appropriate models for investigating FTD's molecular mechanisms has been challenging, as cell lines and animal models do not recapitulate the complex pattern mutations seen in the adult human CNS. Moreover, many studies on tau overexpression models can lead to extreme phenotypes that cannot truly reflect endogenous tau expression in FTD [127]. Interestingly, the ability to reprogram somatic cells into iPSCs may provide an attractive model for studying the pathological mechanism of FTD [133]. iPSCs have become a useful tool to recapitulate FTD patients' disease phenotypes to elucidate the pathogenic mechanisms and accelerate drug discovery [123]. Several studies have recently reported the generation and characterization of familial FTD-patient-derived iPSCs [134]. For example, as reported by Lee et al., FTD-diagnosed patients donated peripheral blood mononuclear cells (PBMCs). Then iPSCs were developed using integration-free CytoTune-iPSC Sendai reprogramming factors, including Sendai virus particles of Oct, Sox2, Klf4, and c-Myc (Yamanaka factors) [135]. In two distinct studies, Rasmussen et al. also successfully established iPSCs from skin fibroblasts of patients diagnosed with FTD carrying R406W and P301L mutations in MAPT to study hereditary FTD and tau pathologies in vitro $[136,137]$. Nimsanor et al. also generated iPSCs from FTD patients carrying an S305I mutation in MAPT [138]. Almeida et al. generated multiple iPSCs from a control subject, a patient with sporadic FTD, and an FTD patient with a novel heterozygous GRN mutation [139]. They successfully identified cell-autonomous, reversible defects in patient neurons with Grn-deficiency and provided an applicable model to study GRN-dependent pathogenic mechanisms and develop potential therapies. Ehrlich et al. also derived iPSCs from patients with FTD-associated MAPT mutations and differentiated them into mature neurons to provide an in vitro model for identifying distinct neurodegenerative changes in frontotemporal dementia with parkinsonism-17 (FTDP-17) [140]. In another study, Kim et al. generated patient-specific iPSC lines from two sporadic FTD patients using their PBMCs and investigated the expression of pathological markers, including FTD-tau, transactive response DNA-binding protein 43 (TDP-43), active caspase-3, and fused in sarcoma (FUS) [141]. Based on their immunocytochemical and immunoblot analyses, the active caspase-3 expression was significantly elevated compared with controls. This neurodegenerative feature of FTD can be used as a potential biomarker to identify pathological mechanisms and therapeutical screening. Raitano et al. also evaluated specific neuronal cells and cortical neurons developed from iPSCs derived from FTD patients to generate a realistic FTD model characterized by selective frontotemporal cortex neurodegeneration [142]. Altogether, although the use of stem cell technology for FTD modeling is still in its infancy, researchers aim to utilize iPSCs as a beneficial tool to facilitate understanding of disease mechanisms and develop treatment strategies.

\section{Challenges and Future Directions}

Despite the remarkable advances in stem cell research for neurodegenerative disorders, several critical issues must be addressed. A major hindrance in stem cell therapies' progression is learning how stem cells work in the body and how they integrate with the targeted tissue/organ. Furthermore, generating specialized cell typologies to overcome tissue- and environmental-specific hurdles are critical requirements. The safe and 
cost-effective generation of these cells in adequate quantities is also another factor to be considered. For example, ESCs and iPSCs can be grown indefinitely in the lab, but the procedures are very complex and demanding, limiting these cells' overall availability.

Furthermore, there is the problem of reducing the risk of post-implant rejection, which adds the burden of needing a close compatible donor for the cells' recipient. Identifying the proper conditions to culture these cells, the most suitable route of administration, delivery, and the target site is also crucial to maximizing the benefit of the treatment and improving the outcome. Unfortunately, most of the data available to researchers were derived from animal studies; therefore, it is unclear whether these human stem cells will afford similar results when administered to a heterogeneous patient population [9]. Unfortunately, animal models are designed to maximize reproducibility at the cost of neglecting the intrinsic variability and diversities between human patients. Directly extrapolating the results from these in vivo studies into human patients is not feasible at this stage. Therefore, animals' structural and functional improvements in these experiments need to be validated in clinical trials [143].

On the other hand, translating stem cell therapy to clinical trials is practically impossible without a suitable stem cell source for therapeutic applications. The cost, time, and labor-intensive nature of stem cell therapy limit its use, especially in developing countries. Additionally, safety considerations, such as the potential for malignant transformation and side effects, such as epilepsy, immune allergic reactions, and injection site injuries, remain significant concerns [144].

The outcome of stem cell therapy can be improved by combining adjunct treatments [48]. For example, stem cell therapy coupled with erythropoietin administration demonstrated synergistic neurogenesis effects in a rat model. Nanoparticle-based delivery systems are being studied to address the shortcomings of stem cell migration and integration into functional networks [145-148]. Nanoparticles are useful in drug and cell delivery systems due to their ability to cross the BBB and reach the targeted brain regions without damaging the surrounding areas. Another alternative to facilitate the delivery and the retention of the stem cells in the transplantation site involves using encapsulation with hydrogels made of hydrophilic polymers, thus providing mechanical support in the delivery processes and increased proliferation and differentiation [149-151]. Recent research studies have also utilized gene therapy and neural growth factors to prolong transplanted stem cells' retention in AD and PD [152]

Despite all the limitations and challenges, stem cell therapy is still a promising approach for treating neurodegenerative diseases in the future [18]. The use of stem cells in neurodegenerative diseases to replace lost neurons and integrate them into existing neural circuitry still seems an unrealistic and long-distant goal [143]. However, using stem cells to deliver therapeutic factors and/or preventing the disease progression appears to be a more realistic and short-term achievable goal. Additional data from ongoing and future clinical trials will provide important insights into the proper delivery approach, immunosuppression, graft survival, and efficacy [113]. With the establishment of best practice guidelines for stem cell therapies, it will be possible to develop novel cellular sources and develop more effective combinatorial approaches to treating neurodegenerative diseases.

\section{Conclusions}

Neurodegenerative diseases have devastating sequelae with conventional pharmacological therapies. To date, progress in the research area of stem cell therapies offers excellent promising methods for the treatment of these disorders. Although much work remains to be done, the growing focus on preclinical studies and the recent translation of some of these therapies to clinical trials has set the stage to continue progress. Using stem cells appears likely to become a key feature of future clinical strategies for treating neurodegenerative disease by replacing dysfunctional neurons and affording neuroprotective and neurorestorative functions. Furthermore, stem cells' recent technological developments involving nanoparticles and hydrogels have made drug delivery and regeneration treatments 
more efficient. Thus, neural replacement and regenerative therapies are soon expected to be successfully translated into the clinical setting.

Author Contributions: F.S. conceived the study and prepared the drafting of the manuscript. L.C. assisted with the drafting of the manuscript and preparation of the figures. L.C. also oversaw the entire project and provided funding support. All authors reviewed the manuscript. All authors have read and agreed to the published version of the manuscript

Funding: This work was supported by the National Institutes of Health/National Institute on Drug Abuse R01DA029121 and R01DA049737, as well as the National Institute of Neurological Disorders and Stroke R01NS117906 to LC.

Institutional Review Board Statement: Not applicable.

Informed Consent Statement: Not applicable.

Data Availability Statement: Data sharing not applicable. No new data were created or analyzed in this study. Data sharing is not applicable to this article.

Conflicts of Interest: The authors declare no conflict of interest.

\begin{tabular}{|c|c|}
\hline \multicolumn{2}{|c|}{ Abbreviations } \\
\hline $\mathrm{AD}$ & Alzheimer's disease \\
\hline ALS & amyotrophic lateral sclerosis \\
\hline BDNF & brain-derived neurotrophic factor \\
\hline CNS & central nervous system \\
\hline DA & dopamine \\
\hline ESCs & embryonic stem cells \\
\hline FTD & frontotemporal dementia \\
\hline GDNF & glial-cell-line-derived neurotrophic factor \\
\hline HD & Huntington's disease \\
\hline IPSCs & induced pluripotent stem cells \\
\hline MSCs & mesenchymal stem cells \\
\hline NFTs & neurofibrillary tangles \\
\hline NGF & nerve growth factor \\
\hline NPCs & neural progenitor cells \\
\hline NSCs & neural stem cells \\
\hline PD & Parkinson's disease \\
\hline ROS & reactive oxygen species \\
\hline SGZ & subgranular zone \\
\hline SVZ & subventricular zone \\
\hline
\end{tabular}

\section{References}

1. De Gioia, R.; Biella, F.; Citterio, G.; Rizzo, F.; Abati, E.; Nizzardo, M.; Bresolin, N.; Comi, G.P.; Corti, S. Neural Stem Cell Transplantation for Neurodegenerative Diseases. Int. J. Mol. Sci. 2020, 21, 3103. [CrossRef] [PubMed]

2. Chang, C.-Y.; Ting, H.-C.; Liu, C.-A.; Su, H.-L.; Chiou, T.-W.; Lin, S.-Z.; Harn, H.-J.; Ho, T.-J. Induced pluripotent stem cell (iPSC)-based neurodegenerative disease models for phenotype recapitulation and drug screening. Molecules 2020, 25, 2000. [CrossRef] [PubMed]

3. Helms, H.C.; Abbott, N.J.; Burek, M.; Cecchelli, R.; Couraud, P.-O.; Deli, M.A.; Förster, C.; Galla, H.J.; Romero, I.A.; Shusta, E.V. In vitro models of the blood-brain barrier: An overview of commonly used brain endothelial cell culture models and guidelines for their use. J. Cereb. Blood Flow Metab. 2016, 36, 862-890. [CrossRef]

4. Sivandzade, F.; Cucullo, L. In-vitro blood-brain barrier modeling: A review of modern and fast-advancing technologies. J. Cereb. Blood Flow Metab. 2018, 38, 1667-1681. [CrossRef] [PubMed]

5. Tam, V.H.; Sosa, C.; Liu, R.; Yao, N.; Priestley, R.D. Nanomedicine as a noninvasive strategy for drug delivery across the blood brain barrier. Int. J. Pharm. 2016, 515, 331-342. [CrossRef]

6. Wen, M.M.; El-Salamouni, N.S.; El-Refaie, W.M.; Hazzah, H.A.; Ali, M.M.; Tosi, G.; Farid, R.M.; Blanco-Prieto, M.J.; Billa, N.; Hanafy, A.S. Nanotechnology-based drug delivery systems for Alzheimer's disease management: Technical, industrial, and clinical challenges. J. Control. Release 2017, 245, 95-107. [CrossRef] [PubMed]

7. Zhang, B.; Yan, W.; Zhu, Y.; Yang, W.; Le, W.; Chen, B.; Zhu, R.; Cheng, L. Nanomaterials in neural-stem-cell-mediated regenerative medicine: Imaging and treatment of neurological diseases. Adv. Mater. 2018, 30, 1705694. [CrossRef] 
8. Lunn, J.S.; Sakowski, S.A.; Hur, J.; Feldman, E.L. Stem cell technology for neurodegenerative diseases. Ann. Neurol. 2011, 70, 353-361. [CrossRef]

9. Sakthiswary, R.; Raymond, A.A. Stem cell therapy in neurodegenerative diseases: From principles to practice. Neural Regen. Res. 2012, 7, 1822.

10. Shariati, A.; Nemati, R.; Sadeghipour, Y.; Yaghoubi, Y.; Baghbani, R.; Javidi, K.; Zamani, M.; Hassanzadeh, A. Mesenchymal stromal cells (MSCs) for neurodegenerative disease; a promising frontier. Eur. J. Cell Biol. 2020, 151097. [CrossRef]

11. Frenette, P.S.; Pinho, S.; Lucas, D.; Scheiermann, C. Mesenchymal stem cell: Keystone of the hematopoietic stem cell niche and a stepping-stone for regenerative medicine. Annu. Rev. Immunol. 2013, 31, 285-316. [CrossRef]

12. Drouin-Ouellet, J.; Barker, R.A. Stem cell therapies for Parkinson's disease: Are trials just around the corner? Regen. Med. 2014, 9 , 553-555. [CrossRef]

13. Dekmak, A.; Mantash, S.; Shaito, A.; Toutonji, A.; Ramadan, N.; Ghazale, H.; Kassem, N.; Darwish, H.; Zibara, K. Stem cells and combination therapy for the treatment of traumatic brain injury. Behav. Brain Res. 2018, 340, 49-62. [CrossRef] [PubMed]

14. Kazmerova, Z.; Zilka, N.; Cente, M.; Neradil, P.; Zilkova, M.; Novak, M. Can we teach old dogs new tricks? Neuroprotective cell therapy in Alzheimer's and Parkinson's disease. J. Alzheimer's Dis. 2013, 37, 251-272. [CrossRef]

15. de Lázaro, I.; Yilmazer, A.; Kostarelos, K. Induced pluripotent stem (iPS) cells: A new source for cell-based therapeutics? J. Control. Release 2014, 185, 37-44. [CrossRef]

16. Sproul, A.A. Being human: The role of pluripotent stem cells in regenerative medicine and humanizing Alzheimer's disease models. Mol. Asp. Med. 2015, 43, 54-65. [CrossRef] [PubMed]

17. Matsumoto, T.; Fujimori, K.; Andoh-Noda, T.; Ando, T.; Kuzumaki, N.; Toyoshima, M.; Tada, H.; Imaizumi, K.; Ishikawa, M.; Yamaguchi, R. Functional neurons generated from T cell-derived induced pluripotent stem cells for neurological disease modeling. Stem Cell Rep. 2016, 6, 422-435. [CrossRef]

18. Wang, Y.; Ji, X.; Leak, R.K.; Chen, F.; Cao, G. Stem cell therapies in age-related neurodegenerative diseases and stroke. Ageing Res. Rev. 2017, 34, 39-50. [CrossRef]

19. Verma, A.; Verma, N. Induced pluripotent stem cells and promises of neuroregenerative medicine. Neurol. India 2011, 59, 555. [CrossRef]

20. Barkho, B.Z.; Zhao, X. Adult neural stem cells: Response to stroke injury and potential for therapeutic applications. Curr. Stem Cell Res. Ther. 2011, 6, 327-338. [CrossRef] [PubMed]

21. Sonntag, K.-C.; Song, B.; Lee, N.; Jung, J.H.; Cha, Y.; Leblanc, P.; Neff, C.; Kong, S.W.; Carter, B.S.; Schweitzer, J. Pluripotent stem cell-based therapy for Parkinson's disease: Current status and future prospects. Prog. Neurobiol. 2018, 168, 1-20. [CrossRef]

22. Glat, M.J.; Offen, D. Cell and gene therapy in Alzheimer's disease. Stem Cells Dev. 2013, 22, 1490-1496. [CrossRef] [PubMed]

23. Chen, X.; Wang, S.; Cao, W. Mesenchymal stem cell-mediated immunomodulation in cell therapy of neurodegenerative diseases. Cell. Immunol. 2018, 326, 8-14. [CrossRef]

24. Vissers, C.; Ming, G.-1.; Song, H. Nanoparticle technology and stem cell therapy team up against neurodegenerative disorders. Adv. Drug Deliv. Rev. 2019, 148, 239-251. [CrossRef] [PubMed]

25. Aleynik, A.; Gernavage, K.M.; Mourad, Y.S.; Sherman, L.S.; Liu, K.; Gubenko, Y.A.; Rameshwar, P. Stem cell delivery of therapies for brain disorders. Clin. Transl. Med. 2014, 3, 24. [CrossRef] [PubMed]

26. Li, Z.; Fan, D.; Xiong, D. Mesenchymal stem cells as delivery vectors for anti-tumor therapy. Stem Cell Investig. 2015, 2. [CrossRef]

27. Hasan, A.; Deeb, G.; Rahal, R.; Atwi, K.; Mondello, S.; Marei, H.E.; Gali, A.; Sleiman, E. Mesenchymal stem cells in the treatment of traumatic brain injury. Front. Neurol. 2017, 8, 28. [CrossRef] [PubMed]

28. Matsushita, T.; Kibayashi, T.; Katayama, T.; Yamashita, Y.; Suzuki, S.; Kawamata, J.; Honmou, O.; Minami, M.; Shimohama, $\mathrm{S}$. Mesenchymal stem cells transmigrate across brain microvascular endothelial cell monolayers through transiently formed inter-endothelial gaps. Neurosci. Lett. 2011, 502, 41-45. [CrossRef]

29. Kar, M.; Shih, Y.-R.V.; Velez, D.O.; Cabrales, P.; Varghese, S. Poly (ethylene glycol) hydrogels with cell cleavable groups for autonomous cell delivery. Biomaterials 2016, 77, 186-197. [CrossRef]

30. Murrell, W.; Palmero, E.; Bianco, J.; Stangeland, B.; Joel, M.; Paulson, L.; Thiede, B.; Grieg, Z.; Ramsnes, I.; Skjellegrind, H.K. Expansion of multipotent stem cells from the adult human brain. PLoS ONE 2013, 8, e71334. [CrossRef]

31. Belenguer, G.; Domingo-Muelas, A.; Ferrón, S.R.; Morante-Redolat, J.M.; Fariñas, I. Isolation, culture and analysis of adult subependymal neural stem cells. Differentiation 2016, 91, 28-41. [CrossRef] [PubMed]

32. Harris, L.; Zalucki, O.; Piper, M.; Heng, J.I.-T. Insights into the biology and therapeutic applications of neural stem cells. Stem Cells Int. 2016, 2016, 9745315. [CrossRef] [PubMed]

33. Carradori, D.; Eyer, J.; Saulnier, P.; Préat, V.; Des Rieux, A. The therapeutic contribution of nanomedicine to treat neurodegenerative diseases via neural stem cell differentiation. Biomaterials 2017, 123, 77-91. [CrossRef]

34. Li, X.; Peng, Z.; Long, L.; Tuo, Y.; Wang, L.; Zhao, X.; Le, W.; Wan, Y. Wnt4-modified NSC transplantation promotes functional recovery after spinal cord injury. FASEB J. 2020, 34, 82-94. [CrossRef]

35. Araque, A.; Carmignoto, G.; Haydon, P.G.; Oliet, S.H.; Robitaille, R.; Volterra, A. Gliotransmitters travel in time and space. Neuron 2014, 81, 728-739. [CrossRef]

36. Bond, A.M.; Ming, G.-1.; Song, H. Adult mammalian neural stem cells and neurogenesis: Five decades later. Cell Stem Cell 2015, 17, 385-395. [CrossRef] [PubMed] 
37. Ming, G.-L.; Song, H. Adult neurogenesis in the mammalian brain: Significant answers and significant questions. Neuron 2011, 70, 687-702. [CrossRef]

38. Nam, H.; Lee, K.-H.; Nam, D.-H.; Joo, K.M. Adult human neural stem cell therapeutics: Current developmental status and prospect. World J. Stem Cells 2015, 7, 126. [CrossRef]

39. López-León, M.; Outeiro, T.F.; Goya, R.G. Cell reprogramming: Therapeutic potential and the promise of rejuvenation for the aging brain. Ageing Res. Rev. 2017, 40, 168-181. [CrossRef]

40. Karussis, D.; Petrou, P.; Kassis, I. Clinical experience with stem cells and other cell therapies in neurological diseases. J. Neurol. Sci. 2013, 324, 1-9. [CrossRef]

41. Yoo, J.; Kim, H.S.; Hwang, D.Y. Stem cells as promising therapeutic options for neurological disorders. J. Cell. Biochem. 2013, 114, 743-753. [CrossRef] [PubMed]

42. Sousa, B.R.; Parreira, R.C.; Fonseca, E.A.; Amaya, M.J.; Tonelli, F.M.; Lacerda, S.M.; Lalwani, P.; Santos, A.K.; Gomes, K.N.; Ulrich, $\mathrm{H}$. Human adult stem cells from diverse origins: An overview from multiparametric immunophenotyping to clinical applications. Cytom. Part A 2014, 85, 43-77. [CrossRef]

43. Stoll, E.A. Advances toward regenerative medicine in the central nervous system: Challenges in making stem cell therapy a viable clinical strategy. Mol. Cell. Ther. 2014, 2, 1-9. [CrossRef]

44. Nicaise, C.; Mitrecic, D.; Falnikar, A.; Lepore, A.C. Transplantation of stem cell-derived astrocytes for the treatment of amyotrophic lateral sclerosis and spinal cord injury. World J. Stem Cells 2015, 7, 380. [CrossRef] [PubMed]

45. Chen, B.K.; Staff, N.P.; Knight, A.M.; Nesbitt, J.J.; Butler, G.W.; Padley, D.J.; Parisi, J.E.; Dietz, A.B.; Windebank, A.J. A safety study on intrathecal delivery of autologous mesenchymal stromal cells in rabbits directly supporting P hase I human trials. Transfusion 2015, 55, 1013-1020. [CrossRef]

46. Fu, M.-H.; Li, C.-L.; Lin, H.-L.; Chen, P.-C.; Calkins, M.J.; Chang, Y.-F.; Cheng, P.-H.; Yang, S.-H. Stem cell transplantation therapy in Parkinson's disease. SpringerPlus 2015, 4, 597. [CrossRef] [PubMed]

47. Oh, K.-W.; Moon, C.; Kim, H.Y.; Oh, S.-I.; Park, J.; Lee, J.H.; Chang, I.Y.; Kim, K.S.; Kim, S.H. Phase I trial of repeated intrathecal autologous bone marrow-derived mesenchymal stromal cells in amyotrophic lateral sclerosis. Stem Cells Transl. Med. 2015, 4, 590-597. [CrossRef]

48. Ritfeld, G.J.; Roos, R.A.; Oudega, M. Stem cells for central nervous system repair and rehabilitation. PMER 2011, 3, S117-S122.

49. Sorrells, S.F.; Paredes, M.F.; Cebrian-Silla, A.; Sandoval, K.; Qi, D.; Kelley, K.W.; James, D.; Mayer, S.; Chang, J.; Auguste, K.I. Human hippocampal neurogenesis drops sharply in children to undetectable levels in adults. Nature 2018, 555, 377-381. [CrossRef]

50. Snyder, J.S. Questioning Human Neurogenesis; Nature: New York, NY, USA, 2018; Volume 555, pp. 315-316.

51. Boldrini, M.; Fulmore, C.A.; Tartt, A.N.; Simeon, L.R.; Pavlova, I.; Poposka, V.; Rosoklija, G.B.; Stankov, A.; Arango, V.; Dwork, A.J. Human hippocampal neurogenesis persists throughout aging. Cell Stem Cell 2018, 22, 589-599.e5. [CrossRef]

52. Gan, L.; Johnson, J.A. Oxidative damage and the Nrf2-ARE pathway in neurodegenerative diseases. Biochim. Biophys. Acta (BBA)-Mol. Basis Dis. 2014, 1842, 1208-1218. [CrossRef] [PubMed]

53. Buddhala, C.; Loftin, S.K.; Kuley, B.M.; Cairns, N.J.; Campbell, M.C.; Perlmutter, J.S.; Kotzbauer, P.T. Dopaminergic, serotonergic, and noradrenergic deficits in Parkinson disease. Ann. Clin. Transl. Neurol. 2015, 2, 949-959. [CrossRef]

54. Ford, E.; Pearlman, J.; Ruan, T.; Manion, J.; Waller, M.; Neely, G.G.; Caron, L. Human Pluripotent Stem Cells-Based Therapies for Neurodegenerative Diseases: Current Status and Challenges. Cells 2020, 9, 2517. [CrossRef]

55. Reddy, A.P.; Ravichandran, J.; Carkaci-Salli, N. Neural regeneration therapies for Alzheimer's and Parkinson's disease-related disorders. Biochim. Biophys. Acta (BBA)-Mol. Basis Dis. 2020, 1866, 165506. [CrossRef]

56. Sivandzade, F.; Prasad, S.; Bhalerao, A.; Cucullo, L. NRF2 and NF-kB interplay in cerebrovascular and neurodegenerative disorders: Molecular mechanisms and possible therapeutic approaches. Redox Biol. 2019, 21, 101059. [CrossRef]

57. Raza, C.; Anjum, R. Parkinson's disease: Mechanisms, translational models and management strategies. Life Sci. 2019, 226, 77-90. [CrossRef] [PubMed]

58. Trombetta-Lima, M.; Sabogal-Guáqueta, A.M.; Dolga, A.M. Mitochondrial dysfunction in neurodegenerative diseases: A focus on iPSC-derived neuronal models. Cell Calcium 2021, 94, 102362. [CrossRef]

59. Kim, H.-J. Stem cell potential in Parkinson's disease and molecular factors for the generation of dopamine neurons. Biochim. Biophys. Acta (BBA)-Mol. Basis Dis. 2011, 1812, 1-11. [CrossRef]

60. Schwarz, J.; Storch, A. Transplantation in Parkinson's disease: Will mesenchymal stem cells help to reenter the clinical arena? Transl. Res. 2009, 155, 55-56. [CrossRef] [PubMed]

61. Takagi, Y.; Takahashi, J.; Saiki, H.; Morizane, A.; Hayashi, T.; Kishi, Y.; Fukuda, H.; Okamoto, Y.; Koyanagi, M.; Ideguchi, M. Dopaminergic neurons generated from monkey embryonic stem cells function in a Parkinson primate model. J. Clin. Investig. 2005, 115, 102-109. [CrossRef] [PubMed]

62. Garitaonandia, I.; Gonzalez, R.; Christiansen-Weber, T.; Abramihina, T.; Poustovoitov, M.; Noskov, A.; Sherman, G.; Semechkin, A.; Snyder, E.; Kern, R. Neural stem cell tumorigenicity and biodistribution assessment for phase I clinical trial in Parkinson's disease. Sci. Rep. 2016, 6, 1-12. [CrossRef]

63. Wang, Y.-K.; Zhu, W.-W.; Wu, M.-H.; Wu, Y.-H.; Liu, Z.-X.; Liang, L.-M.; Sheng, C.; Hao, J.; Wang, L.; Li, W. Human clinical-grade parthenogenetic ESC-derived dopaminergic neurons recover locomotive defects of nonhuman primate models of Parkinson's disease. Stem Cell Rep. 2018, 11, 171-182. [CrossRef] 
64. Tom, C.M.; Younesi, S.; Meer, E.; Bresee, C.; Godoy, M.; Mattis, V.B. Survival of iPSC-derived grafts within the striatum of immunodeficient mice: Importance of developmental stage of both transplant and host recipient. Exp. Neurol. 2017, 297, 118-128. [CrossRef] [PubMed]

65. Deleidi, M.; Cooper, O.; Hargus, G.; Levy, A.; Isacson, O. Oct4-induced reprogramming is required for adult brain neural stem cell differentiation into midbrain dopaminergic neurons. PLoS ONE 2011, 6, e19926. [CrossRef] [PubMed]

66. Yasuhara, T.; Matsukawa, N.; Hara, K.; Yu, G.; Xu, L.; Maki, M.; Kim, S.U.; Borlongan, C.V. Transplantation of human neural stem cells exerts neuroprotection in a rat model of Parkinson's disease. J. Neurosci. 2006, 26, 12497-12511. [CrossRef]

67. Soler, R.; Füllhase, C.; Hanson, A.; Campeau, L.; Santos, C.; Andersson, K.-E. Stem cell therapy ameliorates bladder dysfunction in an animal model of Parkinson disease. J. Urol. 2012, 187, 1491-1497. [CrossRef] [PubMed]

68. Venkataramana, N.K.; Kumar, S.K.; Balaraju, S.; Radhakrishnan, R.C.; Bansal, A.; Dixit, A.; Rao, D.K.; Das, M.; Jan, M.; Gupta, P.K. Open-labeled study of unilateral autologous bone-marrow-derived mesenchymal stem cell transplantation in Parkinson's disease. Transl. Res. 2010, 155, 62-70. [CrossRef]

69. Cave, J.; Wang, M.; Baker, H. Adult subventricular zone neural stem cells as a potential source of dopaminergic replacement neurons. Front. Neurosci. 2014, 8, 16. [CrossRef]

70. Barker, R.A.; Drouin-Ouellet, J.; Parmar, M. Cell-based therapies for Parkinson disease-Past insights and future potential. Nat. Rev. Neurol. 2015, 11, 492. [CrossRef]

71. Han, F.; Baremberg, D.; Gao, J.; Duan, J.; Lu, X.; Zhang, N.; Chen, Q. Development of stem cell-based therapy for Parkinson's disease. Transl. Neurodegener. 2015, 4, 1-13. [CrossRef]

72. Doi, D.; Magotani, H.; Kikuchi, T.; Ikeda, M.; Hiramatsu, S.; Yoshida, K.; Amano, N.; Nomura, M.; Umekage, M.; Morizane, A. Preclinical study of induced pluripotent stem cell-derived dopaminergic progenitor cells for Parkinson's disease. Nat. Commun. 2020, 11, 1-14. [CrossRef]

73. Takahashi, J. Strategies for bringing stem cell-derived dopamine neurons to the clinic: The Kyoto trial. In Progress in Brain Research; Elsevier: Amsterdam, The Netherlands, 2017; Volume 230, pp. 213-226.

74. Okita, K.; Yamakawa, T.; Matsumura, Y.; Sato, Y.; Amano, N.; Watanabe, A.; Goshima, N.; Yamanaka, S. An efficient nonviral method to generate integration-free human-induced pluripotent stem cells from cord blood and peripheral blood cells. Stem Cells 2013, 31, 458-466. [CrossRef]

75. Kim, H.J.; Seo, S.W.; Chang, J.W.; Lee, J.I.; Kim, C.H.; Chin, J.; Choi, S.J.; Kwon, H.; Yun, H.J.; Lee, J.M. Stereotactic brain injection of human umbilical cord blood mesenchymal stem cells in patients with Alzheimer's disease dementia: A phase 1 clinical trial. Alzheimer's Dement. 2015, 1, 95-102. [CrossRef] [PubMed]

76. Politis, M.; Oertel, W.H.; Wu, K.; Quinn, N.P.; Pogarell, O.; Brooks, D.J.; Bjorklund, A.; Lindvall, O.; Piccini, P. Graft-induced dyskinesias in Parkinson's disease: High striatal serotonin/dopamine transporter ratio. Mov. Disord. 2011, 26, 1997-2003. [CrossRef] [PubMed]

77. Bangde, P.; Atale, S.; Dey, A.; Pandit, A.; Dandekar, P.; Jain, R. Potential Gene Therapy Towards Treating Neurodegenerative Disea ses Employing Polymeric Nanosystems. Curr. Gene Ther. 2017, 17, 170-183. [CrossRef] [PubMed]

78. Huang, Y.; Mucke, L. Alzheimer mechanisms and therapeutic strategies. Cell 2012, 148, 1204-1222. [CrossRef]

79. Guo, J.-W.; Guan, P.-P.; Ding, W.-Y.; Wang, S.-L.; Huang, X.-S.; Wang, Z.-Y.; Wang, P. Erythrocyte membrane-encapsulated celecoxib improves the cognitive decline of Alzheimer's disease by concurrently inducing neurogenesis and reducing apoptosis in APP/PS1 transgenic mice. Biomaterials 2017, 145, 106-127. [CrossRef] [PubMed]

80. Association, A.S. 2016 Alzheimer's disease facts and figures. Alzheimer's Dement. 2016, 12, 459-509. [CrossRef]

81. Murphy, S.L.; Xu, J.; Kochanek, K.D. Deaths: Final Data for 2010; National Vital Statistics Reports: Atlanta, GA, USA, 2013; Volume 61, pp. 1-117.

82. Hebert, L.E.; Weuve, J.; Scherr, P.A.; Evans, D.A. Alzheimer disease in the United States (2010-2050) estimated using the 2010 census. Neurology 2013, 80, 1778-1783. [CrossRef] [PubMed]

83. Banigan, M.G.; Kao, P.F.; Kozubek, J.A.; Winslow, A.R.; Medina, J.; Costa, J.; Schmitt, A.; Schneider, A.; Cabral, H.; Cagsal-Getkin, O. Differential expression of exosomal microRNAs in prefrontal cortices of schizophrenia and bipolar disorder patients. PLoS ONE 2013, 8, e48814. [CrossRef]

84. Yeo, R.W.Y.; Lai, R.C.; Zhang, B.; Tan, S.S.; Yin, Y.; Teh, B.J.; Lim, S.K. Mesenchymal stem cell: An efficient mass producer of exosomes for drug delivery. Adv. Drug Deliv. Rev. 2013, 65, 336-341. [CrossRef] [PubMed]

85. Duncan, T.; Valenzuela, M. Alzheimer's disease, dementia, and stem cell therapy. Stem Cell Res. Ther. 2017, 8, 111. [CrossRef]

86. Ager, R.R.; Davis, J.L.; Agazaryan, A.; Benavente, F.; Poon, W.W.; LaFerla, F.M.; Blurton-Jones, M. Human neural stem cells improve cognition and promote synaptic growth in two complementary transgenic models of Alzheimer's disease and neuronal loss. Hippocampus 2015, 25, 813-826. [CrossRef]

87. Kern, D.; Maclean, K.; Jiang, H.; Synder, E.; Sladek Jr, J.; Bjugstad, K. Neural stem cells reduce hippocampal tau and reelin accumulation in aged Ts65Dn Down syndrome mice. Cell Transplant. 2011, 20, 371-379. [CrossRef]

88. Guo, Z.; Zhang, L.; Wu, Z.; Chen, Y.; Wang, F.; Chen, G. In vivo direct reprogramming of reactive glial cells into functional neurons after brain injury and in an Alzheimer's disease model. Cell Stem Cell 2014, 14, 188-202. [CrossRef]

89. Cundiff, P.E.; Anderson, S.A. Impact of induced pluripotent stem cells on the study of central nervous system disease. Curr. Opin. Genet. Dev. 2011, 21, 354-361. [CrossRef] [PubMed] 
90. Penney, J.; Ralvenius, W.T.; Tsai, L.-H. Modeling Alzheimer's disease with iPSC-derived brain cells. Mol. Psychiatry 2020, 25, 148-167. [CrossRef] [PubMed]

91. Takamatsu, K.; Ikeda, T.; Haruta, M.; Matsumura, K.; Ogi, Y.; Nakagata, N.; Uchino, M.; Ando, Y.; Nishimura, Y.; Senju, S. Degradation of amyloid beta by human induced pluripotent stem cell-derived macrophages expressing Neprilysin-2. Stem Cell Res. 2014, 13, 442-453. [CrossRef]

92. Vertelov, G.; Kharazi, L.; Muralidhar, M.; Sanati, G.; Tankovich, T.; Kharazi, A. High targeted migration of human mesenchymal stem cells grown in hypoxia is associated with enhanced activation of RhoA. Stem Cell Res. Ther. 2013, 4, 1-9. [CrossRef]

93. Garcia, K.d.O.; Ornellas, F.L.; Matsumoto, P.; Patti, C.d.L.; Mello, L.E.; Frussa-Filho, R.; Han, S.W.; Longo, B.M. Therapeutic effects of the transplantation of VEGF overexpressing bone marrow mesenchymal stem cells in the hippocampus of murine model of Alzheimer's disease. Front. Aging Neurosci. 2014, 6, 30. [CrossRef] [PubMed]

94. Salem, A.M.; Ahmed, H.H.; Atta, H.M.; Ghazy, M.A.; Aglan, H.A. Potential of bone marrow mesenchymal stem cells in management of Alzheimer's disease in female rats. Cell Biol. Int. 2014, 38, 1367-1383. [CrossRef]

95. Urdzíková, L.M.; Růžička, J.; LaBagnara, M.; Kárová, K.; Kubinová, Š.; Jiráková, K.; Murali, R.; Syková, E.; Jhanwar-Uniyal, M.; Jendelová, P. Human mesenchymal stem cells modulate inflammatory cytokines after spinal cord injury in rat. Int. J. Mol. Sci. 2014, 15, 11275-11293. [CrossRef]

96. Oh, S.H.; Kim, H.N.; Park, H.-J.; Shin, J.Y.; Lee, P.H. Mesenchymal stem cells increase hippocampal neurogenesis and neuronal differentiation by enhancing the Wnt signaling pathway in an Alzheimer's disease model. Cell Transplant. 2015, 24, 1097-1109. [CrossRef]

97. Moreno-Jiménez, E.P.; Flor-García, M.; Terreros-Roncal, J.; Rábano, A.; Cafini, F.; Pallas-Bazarra, N.; Ávila, J.; Llorens-Martín, M. Adult hippocampal neurogenesis is abundant in neurologically healthy subjects and drops sharply in patients with Alzheimer's disease. Nat. Med. 2019, 25, 554-560. [CrossRef] [PubMed]

98. Ma, T.; Gong, K.; Ao, Q.; Yan, Y.; Song, B.; Huang, H.; Zhang, X.; Gong, Y. Intracerebral transplantation of adipose-derived mesenchymal stem cells alternatively activates microglia and ameliorates neuropathological deficits in Alzheimer's disease mice. Cell Transplant. 2013, 22, 113-126. [CrossRef]

99. Kan, I.; Barhum, Y.; Melamed, E.; Offen, D. Mesenchymal stem cells stimulate endogenous neurogenesis in the subventricular zone of adult mice. Stem Cell Rev. Rep. 2011, 7, 404-412. [CrossRef]

100. Martínez-Morales, P.; Revilla, A.; Ocana, I.; Gonzalez, C.; Sainz, P.; McGuire, D.; Liste, I. Progress in stem cell therapy for major human neurological disorders. Stem Cell Rev. Rep. 2013, 9, 685-699. [CrossRef] [PubMed]

101. Hunsberger, J.G.; Rao, M.; Kurtzberg, J.; Bulte, J.W.; Atala, A.; LaFerla, F.M.; Greely, H.T.; Sawa, A.; Gandy, S.; Schneider, L.S. Accelerating stem cell trials for Alzheimer's disease. Lancet Neurol. 2016, 15, 219-230. [CrossRef]

102. Bianchi, F.; Maioli, M.; Leonardi, E.; Olivi, E.; Pasquinelli, G.; Valente, S.; Mendez, A.J.; Ricordi, C.; Raffaini, M.; Tremolada, C. A new nonenzymatic method and device to obtain a fat tissue derivative highly enriched in pericyte-like elements by mild mechanical forces from human lipoaspirates. Cell Transplant. 2013, 22, 2063-2077. [CrossRef] [PubMed]

103. Connor, B. Concise review: The use of stem cells for understanding and treating Huntington's disease. Stem Cells 2018, 36, 146-160. [CrossRef]

104. Ebert, A.D.; Barber, A.E.; Heins, B.M.; Svendsen, C.N. Ex vivo delivery of GDNF maintains motor function and prevents neuronal loss in a transgenic mouse model of Huntington's disease. Exp. Neurol. 2010, 224, 155-162. [CrossRef] [PubMed]

105. Dey, N.D.; Bombard, M.C.; Roland, B.P.; Davidson, S.; Lu, M.; Rossignol, J.; Sandstrom, M.I.; Skeel, R.L.; Lescaudron, L.; Dunbar, G.L. Genetically engineered mesenchymal stem cells reduce behavioral deficits in the YAC 128 mouse model of Huntington's disease. Behav. Brain Res. 2010, 214, 193-200. [CrossRef] [PubMed]

106. Snyder, B.R.; Chiu, A.M.; Prockop, D.J.; Chan, A.W. Human multipotent stromal cells (MSCs) increase neurogenesis and decrease atrophy of the striatum in a transgenic mouse model for Huntington's disease. PLoS ONE 2010, 5, e9347. [CrossRef] [PubMed]

107. Lin, Y.-T.; Chern, Y.; Shen, C.-K.J.; Wen, H.-L.; Chang, Y.-C.; Li, H.; Cheng, T.-H.; Hsieh-Li, H.M. Human mesenchymal stem cells prolong survival and ameliorate motor deficit through trophic support in Huntington's disease mouse models. PLoS ONE 2011,6, e22924. [CrossRef]

108. Snyder, B.R.; Cheng, P.-H.; Yang, J.; Yang, S.-H.; Huang, A.H.; Chan, A.W. Characterization of dental pulp stem/stromal cells of Huntington monkey tooth germs. BMC Cell Biol. 2011, 12, 1-8. [CrossRef] [PubMed]

109. Jeon, I.; Lee, N.; Li, J.Y.; Park, I.H.; Park, K.S.; Moon, J.; Shim, S.H.; Choi, C.; Chang, D.J.; Kwon, J. Neuronal properties, in vivo effects, and pathology of a Huntington's disease patient-derived induced pluripotent stem cells. Stem Cells 2012, 30, $2054-2062$. [CrossRef]

110. An, M.C.; Zhang, N.; Scott, G.; Montoro, D.; Wittkop, T.; Mooney, S.; Melov, S.; Ellerby, L.M. Genetic correction of Huntington's disease phenotypes in induced pluripotent stem cells. Cell Stem Cell 2012, 11, 253-263. [CrossRef]

111. Lin, C.Y.; Wu, C.L.; Lee, K.Z.; Chen, Y.J.; Zhang, P.H.; Chang, C.Y.; Harn, H.J.; Lin, S.Z.; Tsai, H.J. Extracellular Pgk1 enhances neurite outgrowth of motoneurons through Nogo66/NgR-independent targeting of NogoA. Elife 2019, 8, e49175. [CrossRef]

112. Mattis, V.B.; Svendsen, C.N. Induced pluripotent stem cells: A new revolution for clinical neurology? Lancet Neurol. 2011, 10, 383-394. [CrossRef]

113. Raore, B.; Federici, T.; Taub, J.; Wu, M.C.; Riley, J.; Franz, C.K.; Kliem, M.A.; Snyder, B.; Feldman, E.L.; Johe, K. Cervical multilevel intraspinal stem cell therapy: Assessment of surgical risks in Gottingen minipigs. Spine 2011, 36, E164-E171. [CrossRef] 
114. Martínez, H.R.; Molina-Lopez, J.F.; González-Garza, M.T.; Moreno-Cuevas, J.E.; Caro-Osorio, E.; Gil-Valadez, A.; GutierrezJimenez, E.; Zazueta-Fierro, O.E.; Meza, J.A.; Couret-Alcaraz, P. Stem cell transplantation in amyotrophic lateral sclerosis patients: Methodological approach, safety, and feasibility. Cell Transplant. 2012, 21, 1899-1907. [CrossRef] [PubMed]

115. Chiò, A.; Mora, G.; Bella, V.L.; Caponnetto, C.; Mancardi, G.; Sabatelli, M.; Siciliano, G.; Silani, V.; Corbo, M.; Moglia, C. Repeated courses of granulocyte colony-stimulating factor in amyotrophic lateral sclerosis: Clinical and biological results from a prospective multicenter study. Muscle Nerve 2011, 43, 189-195. [CrossRef] [PubMed]

116. Mazzini, L.; Mareschi, K.; Ferrero, I.; Miglioretti, M.; Stecco, A.; Servo, S.; Carriero, A.; Monaco, F.; Fagioli, F. Mesenchymal stromal cell transplantation in amyotrophic lateral sclerosis: A long-term safety study. Cytotherapy 2012, 14, 56-60. [CrossRef] [PubMed]

117. Minguell, J.J.; Allers, C.; Lasala, G.P. Mesenchymal stem cells and the treatment of conditions and diseases: The less glittering side of a conspicuous stem cell for basic research. Stem Cells Dev. 2013, 22, 193-203. [CrossRef]

118. Blanquer, M.; Moraleda, J.M.; Iniesta, F.; Gómez-Espuch, J.; Meca-Lallana, J.; Villaverde, R.; Pérez-Espejo, M.Á.; Ruíz-López, F.J.; Garcia Santos, J.M.; Bleda, P. Neurotrophic bone marrow cellular nests prevent spinal motoneuron degeneration in amyotrophic lateral sclerosis patients: A pilot safety study. Stem Cells 2012, 30, 1277-1285. [CrossRef]

119. Mazzini, L.; Gelati, M.; Profico, D.C.; Sgaravizzi, G.; Pensi, M.P.; Muzi, G.; Ricciolini, C.; Nodari, L.R.; Carletti, S.; Giorgi, C. Human neural stem cell transplantation in ALS: Initial results from a phase I trial. J. Transl. Med. 2015, 13, 1-16. [CrossRef] [PubMed]

120. Petrou, P.; Gothelf, Y.; Argov, Z.; Gotkine, M.; Levy, Y.S.; Kassis, I.; Vaknin-Dembinsky, A.; Ben-Hur, T.; Offen, D.; Abramsky, O. Safety and clinical effects of mesenchymal stem cells secreting neurotrophic factor transplantation in patients with amyotrophic lateral sclerosis: Results of phase $1 / 2$ and 2a clinical trials. JAMA Neurol. 2016, 73, 337-344. [CrossRef]

121. Lunn, J.S.; Sakowski, S.A.; Feldman, E.L. Concise review: Stem cell therapies for amyotrophic lateral sclerosis: Recent advances and prospects for the future. Stem Cells 2014, 32, 1099-1109. [CrossRef]

122. Karageorgiou, E.; Miller, B.L. Frontotemporal Lobar Degeneration: A Clinical approach. Semin Neurol. 2014, 34, 189-201. [CrossRef]

123. Guo, W.; Fumagalli, L.; Prior, R.; Van Den Bosch, L. Current advances and limitations in modeling ALS/FTD in a dish using induced pluripotent stem cells. Front. Neurosci. 2017, 11, 671. [CrossRef] [PubMed]

124. Bang, J.; Spina, S.; Miller, B.L. Frontotemporal dementia. Lancet 2015, 386, 1672-1682. [CrossRef]

125. Capozzo, R.; Sassi, C.; Hammer, M.B.; Arcuti, S.; Zecca, C.; Barulli, M.R.; Tortelli, R.; Gibbs, J.R.; Crews, C.; Seripa, D. Clinical and genetic analyses of familial and sporadic frontotemporal dementia patients in Southern Italy. Alzheimer's Dement. 2017, 13, 858-869. [CrossRef]

126. Greaves, C.V.; Rohrer, J.D. An update on genetic frontotemporal dementia. J. Neurol. 2019, 266, 2075-2086. [CrossRef]

127. Lines, G.; Casey, J.M.; Preza, E.; Wray, S. Modelling Frontotemporal Dementia using patient-derived induced pluripotent stem cells. Mol. Cell. Neurosci. 2020, 109, 103553. [CrossRef]

128. Ferrari, R.; Manzoni, C.; Hardy, J. Genetics and molecular mechanisms of frontotemporal lobar degeneration: An update and future avenues. Neurobiol. Aging 2019, 78, 98-110. [CrossRef]

129. Tang, M.; Gu, X.; Wei, J.; Jiao, B.; Zhou, L.; Zhou, Y.; Weng, L.; Yan, X.; Tang, B.; Xu, J. Analyses MAPT, GRN, and C9orf72 mutations in Chinese patients with frontotemporal dementia. Neurobiol. Aging 2016, 46, 235.e211-235.e215. [CrossRef] [PubMed]

130. Che, X.-Q.; Zhao, Q.-H.; Huang, Y.; Li, X.; Ren, R.-J.; Chen, S.-D.; Wang, G.; Guo, Q.-H. Genetic features of MAPT, GRN, C9orf72 and CHCHD10 gene mutations in Chinese patients with frontotemporal dementia. Curr. Alzheimer Res. 2017, 14, 1102-1108. [CrossRef] [PubMed]

131. Kim, E.-J.; Kim, Y.-E.; Jang, J.-H.; Cho, E.-H.; Na, D.L.; Seo, S.W.; Jung, N.-Y.; Jeong, J.H.; Kwon, J.C.; Park, K.H. Analysis of frontotemporal dementia, amyotrophic lateral sclerosis, and other dementia-related genes in 107 Korean patients with frontotemporal dementia. Neurobiol. Aging 2018, 72, 186.e181-186.e187. [CrossRef]

132. Hedges, E.C.; Mehler, V.J.; Nishimura, A.L. The use of stem cells to model amyotrophic lateral sclerosis and frontotemporal dementia: From basic research to regenerative medicine. Stem Cells Int. 2016, 2016, 9279516. [CrossRef] [PubMed]

133. Karch, C.M.; Kao, A.W.; Karydas, A.; Onanuga, K.; Martinez, R.; Argouarch, A.; Wang, C.; Huang, C.; Sohn, P.D.; Bowles, K.R. A comprehensive resource for induced pluripotent stem cells from patients with primary tauopathies. Stem Cell Rep. 2019, 13, 939-955. [CrossRef] [PubMed]

134. Freibaum, B.D.; Lu, Y.; Lopez-Gonzalez, R.; Kim, N.C.; Almeida, S.; Lee, K.-H.; Badders, N.; Valentine, M.; Miller, B.L.; Wong, P.C. GGGGCC repeat expansion in C9orf72 compromises nucleocytoplasmic transport. Nature 2015, 525, 129-133. [CrossRef] [PubMed]

135. Lee, H.-K.; Morin, P.; Wells, J.; Hanlon, E.B.; Xia, W. Induced pluripotent stem cells (iPSCs) derived from frontotemporal dementia patient's peripheral blood mononuclear cells. Stem Cell Res. 2015, 15, 325-327. [CrossRef]

136. Rasmussen, M.A.; Hjermind, L.E.; Hasholt, L.F.; Waldemar, G.; Nielsen, J.E.; Clausen, C.; Hyttel, P.; Holst, B. Induced pluripotent stem cells (iPSCs) derived from a patient with frontotemporal dementia caused by a P301L mutation in microtubule-associated protein tau (MAPT). Stem Cell Res. 2016, 16, 70-74. [CrossRef]

137. Rasmussen, M.A.; Hjermind, L.E.; Hasholt, L.F.; Waldemar, G.; Nielsen, J.E.; Clausen, C.; Hyttel, P.; Holst, B. Induced pluripotent stem cells (iPSCs) derived from a patient with frontotemporal dementia caused by a R406W mutation in microtubule-associated protein tau (MAPT). Stem Cell Res. 2016, 16, 75-78. [CrossRef] 
138. Nimsanor, N.; Jørring, I.; Rasmussen, M.A.; Clausen, C.; Mau-Holzmann, U.A.; Kitiyanant, N.; Nielsen, J.E.; Nielsen, T.T.; Hyttel, P.; Holst, B. Induced pluripotent stem cells (iPSCs) derived from a symptomatic carrier of a S305I mutation in the microtubule-associated protein tau (MAPT)-gene causing frontotemporal dementia. Stem Cell Res. 2016, 17, 564-567. [CrossRef] [PubMed]

139. Almeida, S.; Zhang, Z.; Coppola, G.; Mao, W.; Futai, K.; Karydas, A.; Geschwind, M.D.; Tartaglia, M.C.; Gao, F.; Gianni, D. Induced pluripotent stem cell models of progranulin-deficient frontotemporal dementia uncover specific reversible neuronal defects. Cell Rep. 2012, 2, 789-798. [CrossRef] [PubMed]

140. Ehrlich, M.; Hallmann, A.-L.; Reinhardt, P.; Araúzo-Bravo, M.J.; Korr, S.; Röpke, A.; Psathaki, O.E.; Ehling, P.; Meuth, S.G.; Oblak, A.L. Distinct neurodegenerative changes in an induced pluripotent stem cell model of frontotemporal dementia linked to mutant TAU protein. Stem Cell Res. 2015, 5, 83-96. [CrossRef] [PubMed]

141. Kim, M.; Kim, H.J.; Koh, W.; Li, L.; Heo, H.; Cho, H.; Lyoo, C.H.; Seo, S.W.; Kim, E.-J.; Nakanishi, M. Modeling of Frontotemporal Dementia Using iPSC Technology. Int. J. Mol. Sci. 2020, 21, 5319. [CrossRef]

142. Raitano, S.; Ordovàs, L.; De Muynck, L.; Guo, W.; Espuny-Camacho, I.; Geraerts, M.; Khurana, S.; Vanuytsel, K.; Tóth, B.I.; Voets, T. Restoration of progranulin expression rescues cortical neuron generation in an induced pluripotent stem cell model of frontotemporal dementia. Stem Cell Rep. 2015, 4, 16-24. [CrossRef]

143. Mirahmadi, M.; Rezanejadbardaji, H.; Irfan-Maqsood, M.; Mokhtari, M.J.; Naderi-Meshkin, H. Stem Cell Therapy for Neurodegenerative Diseases: Strategies for Regeneration against Degeneration. Cell Ther. Regen. Med. J. 2016, 1, 3. [CrossRef]

144. Ding, D.-C.; Lin, C.-H.; Shyu, W.-C.; Lin, S.-Z. Neural stem cells and stroke. Cell Transplant. 2013, 22, 619-630. [CrossRef] [PubMed]

145. Carballo-Molina, O.A.; Sánchez-Navarro, A.; López-Ornelas, A.; Lara-Rodarte, R.; Salazar, P.; Campos-Romo, A.; Ramos-Mejía, V.; Velasco, I. Semaphorin 3C released from a biocompatible hydrogel guides and promotes axonal growth of rodent and human dopaminergic neurons. Tissue Eng. Part A 2016, 22, 850-861. [CrossRef]

146. Garcia-Bennett, A.E.; König, N.; Abrahamsson, N.; Kozhevnikova, M.; Zhou, C.; Trolle, C.; Pankratova, S.; Berezin, V.; Kozlova, E.N. In vitro generation of motor neuron precursors from mouse embryonic stem cells using mesoporous nanoparticles. Nanomedicine 2014, 9, 2457-2466. [CrossRef]

147. Kuo, Y.-C.; Liu, Y.-C.; Rajesh, R. Pancreatic differentiation of induced pluripotent stem cells in activin A-grafted gelatin-poly (lactide-co-glycolide) nanoparticle scaffolds with induction of LY294002 and retinoic acid. Mater. Sci. Eng. C 2017, 77, 384-393. [CrossRef]

148. Kuo, Y.-C.; Rajesh, R. Nerve growth factor-loaded heparinized cationic solid lipid nanoparticles for regulating membrane charge of induced pluripotent stem cells during differentiation. Mater. Sci. Eng. C 2017, 77, 680-689. [CrossRef]

149. Wang, J.; Li, J.; Cai, L. Effects of treatment of cervical spinal cord injury without fracture and dislocation in a medium-to long-term follow-up study. World Neurosurg. 2018, 113, e515-e520. [CrossRef] [PubMed]

150. Perale, G.; Rossi, F.; Santoro, M.; Peviani, M.; Papa, S.; Llupi, D.; Torriani, P.; Micotti, E.; Previdi, S.; Cervo, L. Multiple drug delivery hydrogel system for spinal cord injury repair strategies. J. Control. Release 2012, 159, 271-280. [CrossRef] [PubMed]

151. Zhu, W.; George, J.K.; Sorger, V.J.; Zhang, L.G. 3D printing scaffold coupled with low level light therapy for neural tissue regeneration. Biofabrication 2017, 9, 025002. [CrossRef]

152. Li, Q.; Wang, Z.; Xing, H.; Wang, Y.; Guo, Y. Exosomes derived from miR-188-3p-modified adipose-derived mesenchymal stem cells protect Parkinson's disease. Mol. Ther. Nucleic Acids 2021. [CrossRef] 